\title{
THE PREJUDICES OF EXPERT EVIDENCE
}

Jason M. Chin, ${ }^{1}$ Hayley J. Cullen, ${ }^{2}$ Beth Clarke ${ }^{3}$

${ }^{1}$ School of Law, University of Sydney, ${ }^{2}$ School of Psychological Sciences, University of

Newcastle, ${ }^{3}$ Melbourne School of Psychological Sciences, University of Melbourne

Jason M Chin ORCiD: 0000-0002-6573-2670

Hayley J. Cullen ORCiD: 0000-0002-0406-4912

Beth Clarke ORCiD: 0000-0002-7355-6718

*We thank Gary Edmond, Alex Holcombe, Kristy Martire, Simine Vazire, and Mariam Younan for valuable conversations and feedback on the ideas that gave rise to this article. We are also grateful for the perspicacious comments of two anonymous reviewers.

**This is a pre-publication, author-produced version of an article accepted for publication in the Monash University Law Review following peer review. This article is subject to editorial revision. 


\begin{abstract}
The rules and procedures regulating the admission of potentially unreliable expert evidence have been substantially weakened over the past several years. We respond to this trend by focusing on one aspect of the rules that has not been explicitly curtailed: unfair prejudice. Unfair prejudice is an important component of trial judges' authority to exclude evidence, which they may do when that unfair prejudice outweighs the evidence's probative value. We develop the concept of unfair prejudice by first examining how it has been interpreted by judges and then relating that to the relevant social scientific research on the characteristics of expertise that can make it prejudicial. In doing so, we also discuss the research behind a common reason that judges admit expert evidence despite its prejudice, which is that judicial directions help jurors understand and weigh it. As a result, this article provides two main contributions. First, it advances knowledge about unfair prejudice, which is an important part of expert evidence law that has received relatively little attention from legal researchers. Second, it provides guidance to practitioners for challenging expert evidence under one of the few avenues left to do so.
\end{abstract}




\section{TABLE OF CONTENTS}

$\begin{array}{ll}\text { ABSTRACT } & 1\end{array}$

$\begin{array}{ll}\text { TABLE OF CONTENTS } & 2\end{array}$

$\begin{array}{ll}\text { PART I. INTRODUCTION } & 4\end{array}$

$\begin{array}{ll}\text { PART II. LEGAL FRAMEWORK } & 6\end{array}$

The weakening of the evidence rules that regulate expert evidence 6

$\begin{array}{ll}\text { Unfair prejudice } & 11\end{array}$

PART III. THE PREJUDICES OF EXPERT EVIDENCE 15

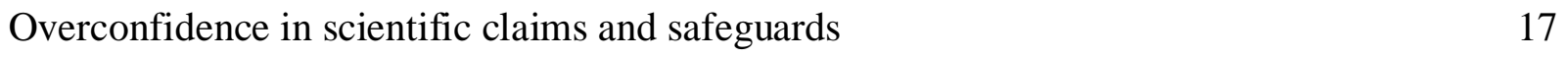

$\begin{array}{lr}\text { The CSI effect(s) } & 20\end{array}$

Expert evidence stereotypes: gender, status, and experience 24

$\begin{array}{ll}\text { Peripheral route processing } & 28\end{array}$

$\begin{array}{ll}\text { An absence of severe tests } & 30\end{array}$

Black box experts

Adversarial imbalance $\quad 34$

Adversarially untested $\quad 35$

What should courts do about the prejudices of expert evidence? 37

PART IV. DO JUDICIAL DIRECTIONS MITIGATE PREJUDICE? 38

PART V. CONCLUSIONS AND FUTURE DIRECTIONS 45 
Table 1. Eight prejudices of expert evidence

Table 2. Disambiguating the CSI Effects

Author Contributions 


\section{PART I. INTRODUCTION}

The current legal regulation of expert evidence in Australian Uniform Evidence Law (' $U E L ')^{1}$ jurisdictions has been criticised for being inadequate, ${ }^{2}$ incoherent, ${ }^{3}$ and difficult to apply in practice. ${ }^{4}$ This state of affairs is worrisome because expert evidence can easily be misused, protracting litigation in the civil context and contributing to wrongful convictions in criminal cases. ${ }^{5}$ In this article, we focus on a part of expert evidence law that has remained relatively unscathed in a time when many other rules that seek to promote accurate factfinding 6 have been pared back. This is the unfair prejudice of expert evidence, which factors into the exclusionary rules in sections 135 and 137 of the $U E L$ that balance probative value against unfair prejudice. ${ }^{7}$ We attempt to provide a fuller understanding of the unfair prejudice jurisprudence by explaining how social scientists, including those who study the research process (i.e.,

\footnotetext{
${ }^{1}$ The following jurisdictions have incorporated the UEL into their evidence rules: The Commonwealth (Evidence Act 1995 (Cth)), the Australian Capital Territory (Evidence Act 2011 (ACT)), New South Wales (Evidence Act 1995 (NSW)), the Northern Territory (Evidence (National Uniform Legislation) Act 2011 (NT)), Tasmania (Evidence Act 2001 (Tas)), Victoria (Evidence Act 2008 (Vic)), Norfolk Island (Evidence Act 2004 (NI)) ('UEL'). Queensland, South Australia, and Western Australia remain common law.

${ }^{2}$ Chris Maxwell, 'Preventing Miscarriages of Justice: The Reliability of Forensic Evidence and the Role of the Trial Judge as Gatekeeper' (2019) 93(8) Australian Law Journal 642; Gary Edmond, 'Icarus and the Evidence Act: Section 137, Probative Value and Taking Forensic Science Evidence 'At Its Highest' (2017) 41(1) Melbourne University Law Review 106.

${ }^{3}$ David Hamer, 'The Unstable Province of Jury Fact-Finding: Evidence Exclusion, Probative Value and Judicial Restraint after IMM v the Queen' (2017) 41(2) Melbourne University Law Review 689; Andrew Roberts, 'Probative Value, Reliability and Rationality' in Andrew Roberts and Jeremy Gans (eds), Critical Perspectives on Uniform Evidence Law (Federation Press, 2017) 63.

${ }^{4}$ Tasmania v Farhat [2017] TASSC 66 [41] ('Farhat'); Langford v Tasmania [2018] TASCCA 1 ('Langford'); Stephen Odgers and Richard Lancaster, 'The probative value of evidence' (Winter 2016) Bar News 36.

${ }^{5}$ For both civil and criminal contexts, see David E Bernstein, 'Expert Witnesses, Adversarial Bias, and the (Partial) Failure of the Daubert Revolution' (2008) 92 Iowa Law Review 451. For a focus on the problems unreliable expert evidence can cause in criminal contexts, see: Brandon L Garrett and Peter J Neufeld, 'Garrett, Brandon L., and Peter J. Neufeld. 'Invalid forensic science testimony and wrongful convictions' (2009) 95(1) Virginia Law Review 1. ${ }^{6}$ Legal researchers refer to this goal of the trial as 'factual rectitude': Kristy A Martire and Gary Edmond, 'Rethinking Expert Evidence' (2017) 40(3) Melbourne University Law Review 967, 967.

${ }^{7}$ This balancing operates differently across provisions. Section 135 applies to all proceedings and grants judges discretion (they 'may refuse to admit evidence') when its probative value is 'substantially outweighed' by unfair prejudice or two other aspects of the evidence. Section 137 applies only to prosecution evidence and the judge 'must refuse to admit evidence' when probative value is outweighed by the danger of unfair prejudice.
} 
metaresearchers), ${ }^{8}$ have studied prejudice. In doing this, we hope to go beyond critiquing the current rules by providing guidance for lawyers seeking to challenge expert evidence.

In Part II, we will review how expert evidence is currently regulated by evidence rules and procedures in $U E L$ jurisdictions. As noted, these safeguards have gradually been weakened, especially as they relate to factual rectitude. We then turn to unfair prejudice, which seems to have untapped potential in helping safeguard the trial against unreliable expert evidence. We explore two themes in the prejudice jurisprudence: evidence that is unfairly prejudicial because it misleads or distracts the factfinder, and evidence that cannot be adequately tested by the party challenging it. Part III builds upon that law by canvassing the prejudices supported by social scientific research. We find that courts have done fairly well, albeit with some confusion, in linking unfair prejudice to findings about how people are prone to misunderstand and overtrust scientific experts. They have not, however, appreciated that much expert evidence is untested and untestable, which is another component of unfair prejudice. Part IV addresses the orthodox reason that judges often ultimately find unfair prejudice to be fair, which is that judicial directions can help the jury understand and properly assign weight to expert evidence. Unlike the situation with prejudice, there is no support for this claim within the social scientific literature. Part V concludes with a summary of the strengths and weaknesses in current research on the prejudice caused by experts, and where that research might go from here.

The following analysis is most relevant to Australian $U E L$ jurisdictions because $U E L$ courts have been the most active in reading the rules of evidence in a way that limits their effect. However, the balancing of probative value against unfair prejudice is a feature of the Australian

\footnotetext{
${ }^{8}$ For a review of metaresearch approaches, see Tom E Hardwicke et al, 'Calibrating the Scientific Ecosystem through Meta-Research' (2020) 7 Annual Review of Statistics and its Application 11.
} 
common law, and evidence law in the US, UK, and Canada. ${ }^{9}$ Moreover, much of the academic work on unfair prejudice in those jurisdictions has occurred in the context of emotionally arousing evidence, ${ }^{10}$ with less focus on expert evidence. As a result, we hope our work will be both broadly applicable, and spark new research questions in this understudied area.

\section{PART II. LEGAL FRAMEWORK}

The weakening of the evidence rules that regulate expert evidence

On the present state of the law $[\ldots]$ the judge in a criminal trial is unable to perform the

"gatekeeper" role as defined in [previous authorities]. ${ }^{11}$

Over the past decade $U E L$ courts have either declined to strengthen the rules of evidence that regulate expert witnesses or substantially weakened them - especially in relation to rules aimed at promoting factual accuracy. ${ }^{12}$ Here, we provide only a brief review of this phenomenon because it has been detailed by other legal researchers and commentators. ${ }^{13} \mathrm{We}$ will begin with the foundational rule governing the admissibility of expert evidence (section 79) and from there turn to the expert witness code of conduct, ending with the trial judge's authority to exclude evidence when the probative value of the evidence is exceeded by its unfair prejudice.

Section 79 is the primary admissibility rule for expert opinion evidence. It presents an exception to the general exclusion of opinion evidence by allowing opinion evidence if the witness 'has specialised knowledge based on the person's training, study or experience' and that opinion is 'wholly or substantially based on that knowledge'.${ }^{14}$ Courts in the US and Canada

\footnotetext{
${ }^{9}$ Pentland $v$ The Queen [2020] QSCPR 10 ('Pentland'); Federal Rules of Evidence, 28 USC r 403 ('FRE'); Police and Criminal Evidence Act 1984, c 60, s 78 ('PACE'); R v Morris [1983] 2 SCR 190 ('Morris').

${ }^{10}$ See a recent summary of this large body of research in Jessica M Salerno, 'The Impact of Experienced and Expressed Emotion on Legal Factfinding' (2021) Annual Review of Law and Social Science.

${ }^{11}$ Maxwell (n 2) 643.

${ }^{12}$ See sources at $\mathrm{n} 2-3$. On the relegation of factual rectitude in US evidence law, see Dan Simon: 'The Limited Diagnosticity of Criminal Trials' (2011) 64(1) Vanderbilt Law Review 143.

${ }^{13}$ See sources at $n$ 2-3.

14 s 79, UEL (n 1).
} 
have held that knowledge connotes some level of demonstrable reliability. ${ }^{15}$ In other words, those jurisdictions, in theory, ${ }^{16}$ require that the evidence's proponent provide something more than the mere say-so of the expert, such as whether the expert's practices have been tested in some way. This interpretation has the capacity to help safeguard the trial against serious problems, like the well-documented issue of untested forensic scientific practices contributing to wrongful convictions in Australia and abroad. ${ }^{17}$

Despite urging from some legal researchers, ${ }^{18}$ Australian courts have refrained from reading reliability into section 79 . Many of the leading cases in this area concern the scientifically untested practice of forensic 'body-mapping' or body comparison. ${ }^{19}$ This practice likely arose from the increasing availability of CCTV footage and, in particular, footage of individuals with their faces shrouded such that their faces are difficult to identify. Body-mappers compare various aspects of the bodies (e.g., the shape of the head) of the individual in the CCTV images with the accused, and provide a positive identification or several points of comparison. ${ }^{20}$

Australian courts have consistently sidestepped reliability issues with body-mapping. In $R v$ Tang, the New South Wales Court of Criminal Appeal said that the 'focus of attention must be on the words "specialised knowledge", not on the introduction of an extraneous idea such as

\footnotetext{
${ }^{15}$ Daubert v Merrell Dow Pharmaceuticals Inc, 509 US 579 (1993), 113 S Ct 2786; Rv Trochym, 2007 SCC 6, [2007] 1 SCR 239.

${ }^{16}$ Researchers in the US find that the reliability requirement is applied less vigorously in criminal cases: Peter J Neufeld, 'The (Near) Irrelevance of Daubert to Criminal Justice and Some Suggestions for Reform' (2005) 95(S1) American Journal of Public Health S107. In Canada see a discussion in Jason M Chin and D'Arcy White, 'Forensic bitemark identification evidence in Canada' (2019) 52(1) UBC Law Review 57.

${ }^{17}$ Rachel Dioso-Villa, 'A Repository of Wrongful Convictions in Australia: First Steps toward Estimating Prevalence and Causal Contributing Factors' (2015) 17(2) Flinders Law Journal 163.

18 Gary Edmond and Mehera San Roque, 'Honeysett v The Queen: Forensic Science, 'Specialised Knowledge' and the Uniform Evidence Law’ (2014) 36 Sydney Law Review 323.

${ }^{19} R v$ Tang [2006] NSWCCA 167 ('Tang'); Morgan v The Queen [2011] NSWCCA 257 ('Morgan'); Honeysett v The Queen [2014] HCA 29 ('Honeysett').

${ }^{20}$ Body-mappers have resiled from offering absolute identifications, but still offer quite strong identifying evidence. See the absolute identification in Tang (n 19) [33] 'Given the number of matches I'm of the opinion that they're one in the same'. In Honeysett ( $\mathrm{n}$ 19) [17], this had evolved to 'he was unable to discern any anatomical dissimilarity between the two individuals'.
} 
"reliability", ${ }^{21}$ And, despite a critical review of body-mapping in Morgan v the Queen (albeit in obiter), ${ }^{22}$ the High Court elided the issue of reliability again in Honeysett $v$ The Queen. ${ }^{23}$ In that case, the accused put reliability squarely at issue: '[the accused] contends that in order to constitute an area of "specialised knowledge" there must be an independent means of gauging the reliability and validity of an opinion based on that knowledge. ${ }^{24}$ Instead of addressing that submission, the High Court held that the expert, an anatomy professor, ran afoul of section 79 because his opinion was too far removed from his expertise; it was not based on his specialized knowledge..$^{25}$ Decisions like these leave open the possibility that an expert will simply declare an expertise in body-mapping without providing any evidence of its reliability, as experts have done in other fields in the past. ${ }^{26}$

A year after Honeysett, and outside of the body-comparison context, the Victorian Court of Appeal in Tuite v The Queen went further than merely sidestepping reliability's role in section 79. Rather, it expressly held that the current wording of section 79 could not accommodate reliability: 'the language of s 79(1) leaves no room for reading in a test of evidentiary reliability as a condition of admissibility. ${ }^{27}$ This decision did, however, indicate that reliability, and especially scientific validation, were central to assessing the probative value of expert evidence. ${ }^{28}$ Accordingly, a lack of demonstrable reliability could be cause to exclude evidence

\footnotetext{
${ }^{21}$ Tang (n 19) [137].

${ }^{22}$ Morgan (n 19) [103]-[147].

${ }^{23}$ Honeysett (n 19).

${ }^{24}$ Ibid [38].

${ }^{25}$ Ibid [42]-[43].

${ }^{26}$ See Chin and White (n 16); Jennifer L Mnookin, 'The Uncertain Future of Forensic Science' (2018) 147 Daedalus 99.

${ }^{27}$ Tuite v The Queen [2015] VSCA 148 [70] ('Tuite’).

${ }^{28}$ Ibid [85]-[106].
} 
under sections 135 and 137, which balance probative value against unfair prejudice and other factors.

Tuite's guidance regarding probative value was tacitly overruled just a year later in the controversial High Court decision, IMM $v$ The Queen. ${ }^{29}$ IMM held that, when assessing probative value, courts must assume that the evidence is maximally reliable and credible (i.e., take those qualities of evidence at their highest). ${ }^{30}$ Although this decision could have been confined to its facts, which was tendency and prior complaint evidence, it has been widely applied to several forms of evidence, including expert evidence. ${ }^{31} I M M$ has drawn criticism and expressions of confusion from researchers, ${ }^{32}$ practitioners, ${ }^{33}$ courts,${ }^{34}$ and one judge writing extra-judicially. ${ }^{35}$ One theme of this criticism is that the decision robs judges of their ability to keep unreliable evidence from the jury. ${ }^{36}$ Another theme concerns inconsistencies within the judgment, which make it difficult for lower courts to faithfully apply. ${ }^{37}$

$I M M$ also stripped expert witness codes of conduct of their force. ${ }^{38}$ Expert witness codes of conduct seek to improve expert evidence by reminding experts of their overriding duty to the court (rather than the retaining party) and encouraging behaviour that supports that duty. These include acknowledging limitations and fully reporting the facts and other opinions that the expert

${ }^{29} I M M v$ The Queen [2016] HCA 14 ('IMM'); See critiques in the sources at notes 2-3.

${ }^{30} \operatorname{IMM}$ (n 29) [50].

${ }^{31}$ Jason M Chin, Gary Edmond, and Andrew Roberts 'Simply Unconvincing: The High Court on Probative Value and Reliability in the Uniform Evidence Law' (2021) Federal Law Review.

${ }^{32}$ Edmond (n 2); Hamer (n 3); Roberts (n 3).

33 Odgers and Lancaster (n 4).

${ }^{34}$ Farhat (n 4) [41]; Langford (n 4).

35 Maxwell (n 2).

${ }^{36}$ Maxwell (n 2); Edmond (n 2).

${ }^{37}$ Langford (n 4) [56]; Farhat (n 4) [41]: 'confess to some difficulty in resolving the proper approach to the evidence in light of the identification example given by the majority in IMM. Identification evidence is unconvincing but that is because it is unreliable'.

${ }^{38}$ See Jason M Chin, Mehera San Roque, and Rory McFadden, 'The New Psychology of Expert Witness Procedure' (2020) 42(1) Sydney Law Review 69. 
is relying on. Prior to $I M M$, courts had refrained from treating breaches of codes of conduct as going to admissibility per $s e .{ }^{39}$ Rather, failing to follow the code reduced evidence's probative value, increasing the possibility that it could be excluded under sections 135 or $137 .{ }^{40}$ However, after $I M M$, breaches of codes of conduct, which are largely matters of reliability, appear to have no bearing on admissibility because reliability must be taken at its highest. ${ }^{41}$

Finally, at common law, experts faced the additional admissibility hurdle known as the basis rule. ${ }^{42}$ In short, they were required to identify their assumptions, prove the facts they relied on, and clearly state their reasoning to ensure the court could assess 'the rational force' 43 of their evidence. ${ }^{44}$ This would appear to be a salutary requirement insofar as it requires experts to be transparent about the strengths and limits of their expertise and the inquiry they conducted ( that this expansive version of the basis rule no longer operates in $U E L$ jurisdictions. ${ }^{46}$ Rather, pursuant to section 79 , the party tendering the evidence must simply demonstrate that the evidence is 'wholly or substantially' based on the witness's specialised knowledge. ${ }^{47}$ The majority in Dasreef Pty Ltd v Hawchar described this as a low bar that in most cases 'will

\footnotetext{
${ }^{39}$ See Kyluk Pty Ltd v Chief Executive, Office of Environment and Heritage [2013] NSWCCA 114 [61] ('Kyluk'). ${ }^{40}$ See Chin, San Roque, and McFadden (n 38) 88; Indeed, at least one case excluded an expert under this theory: Kyluk (n 39) [61]-[68].

${ }^{41}$ Chen v The Queen [2018] NSWCCA 106 [46]-[75] ('Chen'); See Chin, San Roque, McFadden (n 38) 88-90. Although outside the scope of this article, strengthening or more broadly applying other procedural mechanisms to mitigate bias in expert evidence may be helpful. One possibility is, as is more common in civil cases, asking expert witnesses to provide their evidence concurrently, in what is known as 'hot-tubbing'. Note, however, that one recent study found little benefit to this procedure in reducing bias: Jennifer T Perillo et al, 'Testing the waters: An investigation of the impact of hot tubbing on experts from referral through testimony' (2021) 45(3) Law and Human Behavior 229.

${ }^{42}$ Dasreef Pty Ltd v Hawchar [2011] HCA 21 [64]-[94] ('Dasreef'); Makita (Australia) Pty Ltd v Sprowles [2001] NSWCA 305 [59]-[86] ('Makita').

${ }^{43}$ Dasreef (n 42) [93].

44 JD Heydon, Cross on Evidence (LexisNexis, 10th ed, 2015) 1027-40.

${ }^{45}$ Rachel Searston and Jason M Chin, 'The legal and scientific challenges of black box expertise' (2019) 38(2) University of Queensland Law Journal 238, 250-3.

${ }^{46} H G v$ The Queen [1999] HCA 2 [63] ('HG'); Langford (n 4) [38]; Kyluk (n 39) [117].

${ }^{47}$ UEL (n 1) s 79.
} 
require little explicit articulation or amplification once the witness has described his or her qualifications and experience, and has identified the subject matter about which the opinion is proffered.' ${ }^{48}$

\section{$\underline{\text { Unfair prejudice }}$}

Unlike the rules above, a judge's assessment of evidence's unfair prejudice has not been explicitly curtailed by $U E L$ jurisprudence. Here, in order to lay the groundwork for our discussion of the prejudices studied by social scientists and metaresearchers, we will briefly review the relevant law of unfair prejudice. ${ }^{49}$ This will include some cases in which courts have considered social scientific evidence in understanding whether there was unfair prejudice in the instant case.

Unfair prejudice has not been exhaustively defined, but the concept has been explored in a great deal of $U E L$ jurisprudence. ${ }^{50}$ The Australian Law Reform Commission, in a report preceding the $U E L$, described unfairly prejudicial evidence as that which would mislead the factfinder in some way, such as by provoking an emotional response or causing them to decide on the basis of reasons unconnected to the case. ${ }^{51}$ Subsequent jurisprudence, however, generally agreed that unfair prejudice is not limited to evidence that actively misleads and distracts, but

\footnotetext{
${ }^{48}$ Dasreef (n 42) [37]; we note, however, that it would be open to judges to question expert witnesses about the factual basis of their opinion, which may help expose situations in which there is little such basis - we are unaware of any data regarding how common such practices are.

${ }^{49}$ Despite slight textual differences 135 ('unfairly prejudicial') and 137 ('unfair prejudice') of the $U E L$, and courts treat the term is meaning the same thing across those provisions: Ainsworth $v$ Burden [2005] NSWCA 174 [99]; $R v$ Bauer [2018] HCA 40 [73]. As a result, in summarising the law surrounding unfair prejudice, we will discuss both s 135 and 137 interpretations.

${ }^{50}$ John Anderson, Uniform Evidence Law Text and Essential Cases (Federation, 4th ed, 2021) 120; See also Stephen Odgers, Uniform Evidence Law (Thomson Reuters, 13th ed, 2018) 1251-57, 1291-1302.

${ }^{51}$ Australian Law Reform Commission, Evidence (Report No 26, 1985) 351-352 ('ALRC 26’).
} 
could also be found in the adverse party's 'inability to test the reliability of evidence'. ${ }^{52} \mathrm{We}$ will address these two expressions of unfair prejudice as they relate to expert evidence in turn.

Beginning with factfinders being misled by some aspect of the expert evidence, ${ }^{53}$ courts have acknowledged that unfair prejudice may flow from an expert's status giving them a 'spurious appearance of authority'. ${ }^{4}$ This has been described as a 'white coat' effect. ${ }^{55}$ In Keller $v$ The Queen, for instance, the New South Wales Court of Criminal Appeal held that a police officer's expert evidence was unfairly prejudicial because the jury might simply accept his opinion about drug terminology due to his status as a police officer. ${ }^{56}$

As a manifestation of the white coat effect, courts have sometimes considered the controversial social scientific finding known as the 'CSI Effect' 57 We will discuss the CSI Effect further in Part III, but suffice it to say that most courts have interpreted the CSI Effect as causing lay factfinders to place too much weight on forensic science evidence due to the way it is portrayed in popular culture and its general scientific aura. For instance, in DPP $v$ Wise, the Victorian Court of Appeal upheld the exclusion of expert evidence indicating that the accused's DNA was found on the clothing of the complainant. ${ }^{58}$ There were several innocent explanations

\footnotetext{
${ }^{52}$ Australian Law Reform Commission, Uniform Evidence Law (Report No 102, December 2005) 564 ('ALRC 102'); La Trobe Capital \& Mortgage Corp Ltd v Hay Property Consultants Pty Ltd [2011] FCAFC 4 [61]-[73] ('La Trobe'); $R$ v Suteski [2002] NSWCCA 509 [126] ('Suteski').

${ }^{53}$ Another source of unfair prejudice is the emotional response that some evidence may provoke, such as when the jury views gruesome crime scene photos or hears about the accused's sordid past. See: ALRC 102 (n 52) 564;

Salerno ( $\mathrm{n}$ 10). This expression of unfair prejudice is unlikely to be engaged by expert evidence, unless that expert is relying on some emotional facts to support their opinion.

${ }^{54}$ HG (n 46) [44]; Rees v Lumen Christi Primary School [2010] VSC 514 [50] ('Rees').

${ }^{55} R$ v Dirani [2018] NSWSC 891 [112] ('Dirani'); Morgan (n 19) [146], note however, the discussion in Morgan did not pertain to unfair prejudice per se.

${ }^{56}$ Keller v The Queen [2006] NSWCCA 204 [43].

${ }^{57}$ Kimberlianne Podlas, 'The "CSI Effect"' in Henry N Pontell (ed), Oxford Research Encyclopedia of Criminology and Criminal Justice (Oxford University Press, 2017); Jason M Chin and Larysa Workewych, 'The CSI effect' in Markus Dubber (ed), Oxford Handbooks Online (Oxford University Press, 2016).

${ }^{58}$ DPP v Wise [2016] VSCA 173 ('Wise').
} 
for that DNA transfer, which limited its probative value. The court referenced the CSI Effect in supporting its conclusion that there was also high unfair prejudice: ${ }^{59}$

...one of the dangers associated with DNA evidence, is what has come to be known as the 'CSI effect'. The 'CSI effect' is a reference to the atmosphere of scientific confidence evoked in the imagination of the average juror by descriptions of DNA findings [...] a jury will likely regard it as being cloaked in an unwarranted mantle of legitimacy — no matter the directions of a trial judge — and give it weight that it simply does not deserve. The danger of unfair prejudice is thus marked...

The court in DPP v Paulino came to the same conclusion. ${ }^{60}$ As we will see in Part III, there is some understandable confusion in Australian courts about the strength of research behind the CSI Effect, which we will attempt to rectify.

Another aspect of expert evidence, beyond the characteristics of the witness, is whether the statistics and associated technical information they present can cause jurors to give evidence more weight than it deserves ${ }^{61}$ For instance, the evidence may be technical and confusing to the factfinder, leading them to rely on it without fully understanding it. ${ }^{62}$ Courts have also sometimes excluded evidence when the statistic presented may have presented in a way that made it seem

\footnotetext{
${ }^{59}$ Ibid [70].

${ }^{60}$ [2017] VSCA 38 ('Paulino') [24]: 'As I have indicated, the DNA found on the shoe, and in the car, had virtually no probative value, and was therefore irrelevant. On the other hand, the DNA found on the shirt and jacket, though (just) passing the test of relevance, was of relatively little probative value. That fact, when coupled with the dangers of the 'CSI effect' (as to which any direction by the judge in a case such as this would only be of doubtful utility) meant that exclusion under s 137 was clearly warranted.'; Expert evidence was also excluded because of the CSI Effect (among other reasons in the following cases: $R v$ Beowulf [2019] ACTSC 64 [41]; $R v K E$ [2019] NSWDC 349 [42]; $R v R \&$ Nasradden [2017] SADC 111 [138]; Despite the courts in the following cases seeming to accept the CSI Effect, evidence was admitted due, in part, on reliance on directions that would mitigate the CSI Effect: Vyater v The Queen [2020] VSCA 32 [86]; Ramaros v The Queen [2018] VSCA 143 [46] ('Ramaros'); Davies v The Queen [2019] VSCA 66 [189]; Farha v The Queen [2018] VSCA 310 [37]. ${ }^{61}$ Aytugrul v The Queen [2012] HCA 15 [17] ('Aytugrul'); $R$ v GK [2001] NSWCCA 413 ('GK'); $R$ v Galli [2001] NSWCCA 504 ('Galli'); The Queen v Dagger [2017] NTSC 19 [40] ('Dagger'). ${ }^{62}$ Dagger (n 61) [40],
} 
misleadingly large. ${ }^{63}$ Although note that, the High Court in Aytugrul $v$ The Queen refrained from finding such a statistic was unfairly prejudicial. ${ }^{64}$

Evidence may also be unfairly prejudicial when a party is unable to fully test its reliability. ${ }^{65}$ This can occur when the evidence is hearsay, such as a pre-written or recorded statement. ${ }^{66}$ It may also occur when, for some reason, the memory of the witness is poor. ${ }^{67}$ In $D P P \vee J G$, for instance, the witness had undergone hypnosis to recover the relevant memories. ${ }^{68}$ The court was concerned that the answers she subsequently gave may have been affected by suggestions introduced by the therapist in ways that could not be tested due to their unconscious nature.

In the context of expert evidence, the issue of testability arises when some of the material underlying an expert's opinion is unavailable. ${ }^{69}$ For example, in Kyluk Pty Ltd $v$ Chief Executive, Office of Environment and Heritage, the expert testified that he relied heavily on a report that was not in evidence..$^{70}$ The unavailability of this report contributed to the exclusion of the expert's evidence for unfair prejudice: 'without the material from the laboratory being in evidence, the appellant could not evaluate and test the cogency of the conclusions expressed by

\footnotetext{
${ }^{63}$ GK (n 61); Galli (n 61).

${ }^{64}$ Aytugrul (n 61) [32].

${ }^{65}$ Sutesky (n 52); Corkhill v Commonwealth of Australia [2016] ACTSC 100 [37]; R v Bufton (Ruling No 1) [2019] VSC 232 [110]; La Trobe (n 52) [67]; Anderson v St Andrews Village Ballina t/as St Andrews Village Ballina Ltd [2020] FCCA 3231 [62] ('Anderson'); Grocon Constructors (QLD) Pty Ltd v Dexus Funds Management Ltd as Trustee for Dexus 480Q Trust [2019] FCA 601 [18] ('Grocon'); Unilever Australia Ltd v Revlon Australia Pty Ltd (No 6) [2014] FCA 1409 [10] ('Unilever'); Galvin v The Queen [2006] NSWCCA 66 [4]-[42]; Matthews v SPI Electricity Pty Ltd (Ruling No 35) [2014] VSC 59 [56].

${ }^{66}$ Seven Network Ltd v News Ltd (No 8) [2005] FCA 1348; Munro v The Queen [2014] ACTCA 11 [81]-[87]. Privilege may also make it impossible to test part of the evidence: Grocon (n 65) [18].

${ }^{67} D P P$ v $J G$ [2010] NSWCCA 222 (' $J G$ '); $R$ v SG [2017] NSWCCA 202 [44], [47].

68 '...the questions which arose for consideration included whether a crucial suggestion made to a young child through inappropriate questioning, may have resulted in a memory being created and possibly enhanced by later hypnosis, as well as other difficulties, so as to give rise to unfair prejudice of the kind to which s 137 is directed': $J G$ (n 67) [214].

${ }^{69}$ Kyluk (n 39); $R$ v Sing [2002] NSWCCA 20 ('Sing'); Citrus Queensland Pty Ltd v Sunstate Orchards Pty Ltd (No 7) [2008] FCA 1364 [328]-[356] ('Citrus').

${ }^{70}$ Kyluk (n 39) [65].
} 
[the expert witness] and was unfairly disadvantaged. ${ }^{71}$ Similarly, in $R v$ Sing, an expert opinion was excluded because the individual who provided the testing underlying that opinion was unavailable. ${ }^{72}$ This inability to fully examine expert evidence is heightened when it is complex. ${ }^{73}$ On the other hand, when evidence is 'straightforward' 74 with strengths and weaknesses that are apparent on their face, the lack of testability may not be fatal. ${ }^{75}$ Similarly, if there are ways to test the evidence that the party did not take up, then this can reduce the unfair prejudice. ${ }^{76}$

\section{PART III. THE PREJUDICES OF EXPERT EVIDENCE}

As we saw in Part II, expert evidence can be unfairly prejudicial when it misleads the factfinder and when it is untestable by the party challenging it. We will now explore eight prejudices (and categories of prejudice) that are expressions of those two themes. We will focus on prejudices that have been studied by social scientists and other researchers, sometimes extending research conducted in non-legal contexts to explain how it may be applied to evaluations of expert evidence (flagging when we make these leaps).

[Table 1 about here]

Table 1 provides a brief summary of this part: the eight prejudices, the way in which they introduce prejudice, a key study or summary readers can rely on, and a legal authority suggesting a prejudice of this type can be cause to exclude the evidence to which it applies (if one is available). The analysis proceeds in the order laid out in Table 1. We start with prejudice stemming from evidence that misleads the factfinder and, in particular, (1) research supporting

\footnotetext{
${ }^{71}$ Ibid [66].

72 Sing (n 69) [34]; See also Citrus (n 69) [341].

${ }^{73}$ Anderson (n 65) [64]; Unilever (n 65) [10]; Dagger (n 61) [40].

${ }^{74}$ La Trobe (n 52) [62].

${ }^{75}$ Charan v Nationwide News Pty Ltd [2018] VSC 3 [507] ('Charan').

${ }^{76}$ Australian Competition and Consumer Commission (ACCC) v Yazaki Corp (No 2) [2015] FCA 1304 [66]; Solis v The Queen [2018] VSCA 275 [86].
} 
that laypeople are overconfident in scientific claims and safeguards. We focus on newer research reinforcing longstanding concerns that the public is likely unaware of the degree of selective reporting and irreproducibility in scientific fields. Relying on that groundwork, we then drill down into the sometimes misunderstood (2) CSI effect, which suggests that the popular culture depiction of forensic science can lead prospective jurors to think that field is more reliable than it is. The CSI effect is only the tip of the iceberg and seems to have distracted courts from recognising many other (3) expert evidence stereotypes, such as factfinders assuming high status experts and those with greater experience are more reliable. This part of the tour ends with (4) peripheral route processing, which suggests that laypeople are more likely to fall prey to misconceptions and stereotypes about expertise when they do not have the cognitive resources, knowledge, or motivation to assess the expert evidence systematically.

We then move on to prejudices more closely associated with the difficulty or impossibility of testing some evidence. This begins with (5) the absence of severe testing in many fields (i.e., tests that would be likely to reveal errors if those errors did exist). We then turn to expertise that is difficult to test because it relies on unconscious, subjective processes that occur in the (6) black box of the expert's mind. We end with two system-related reasons evidence is untestable or difficult to test: (7) adversarial imbalance, or the reality that many accused people do not have the resources to fully test the prosecution's evidence, and the result of that imbalance, which is that (8) many forms of expert evidence that the legal system likely assumes have been robustly adversarially tested, have not been. 
$\underline{\text { Overconfidence in scientific claims and safeguards }}$

Social scientists studying the scientific process have long warned about the dangers of science in the courtroom..$^{77}$ These admonitions include that lay factfinders would place too much weight on scientific evidence and that courts might struggle drawing a line between science and junk science. ${ }^{78}$ As we will now suggest, these issues are just as pressing now as they were then. In fact, recent empirical research prompted by a well-documented 'reproducibility crisis' provides evidence of more specific and actionable misunderstandings that laypeople are likely to have about scientific research. The reproducibility crisis refers to the startling finding in many fields (e.g., medicine, cancer biology, psychology) that effects which were once considered robust by scientific standards (e.g., published in a peer reviewed journal) cannot be reproduced by independent labs. ${ }^{79}$

Although the reasons that research may be unreliable are many, ${ }^{80}$ for brevity we will limit most of our discussion to the problematic research practice of 'selective reporting'. It is also an issue that arises below when we discuss how scientific claims are tested. Selective reporting

\footnotetext{
${ }^{77}$ Sheila Jasanoff, 'What Judges Should Know About the Sociology of Science' (1992) 32(3) Jurimetrics 348. Beyond critiques from the sociology of science, see Tal Golan, 'The History of Scientific Expert Testimony in the English Courtroom' (1999) 12(1) Science in Context 7.

${ }^{78} \mathrm{Ibid}$. In the philosophy of science, this problem is referred to as the 'demarcation problem': Karl R Popper The logic of scientific discovery (Basic Books, 1959). After decades of searching for an answer, philosophers have still not reached consensus on this issue. However, there is agreement that a single infallible scientific method does not suffice as the demarcating criteria, simply because no such method exists in practice: Naomi Oreskes, Why Trust Science? (Princeton University Press, 2019) 55. In reality, scientific activity operates via several different methods, all of which are ultimately driven by fallible researchers and to some extent, their values: Massimo Pigliucci, 'The Demarcation Problem. A (Belated) Response to Laudan' in Massimo Pigliucci and Maarten Boudry (eds), Philosophy of pseudoscience: Reconsidering the demarcation problem (University of Chicago Press, 2013) 9. Some philosophers argue that the pursuit for demarcation criteria is hopeless and should be abandoned: Larry Laudan, 'The Demise of the Demarcation Problem' in Robert S Cohen and R Laudan (eds), Physics, Philosophy and Psychoanalysis (Springer, 1983) 111.

${ }^{79}$ Glenn Begley and Lee M Ellis, 'Comment: Raise Standards for Preclinical Cancer Research' (2012) 483(7391) Nature 531; John PA Ioannidis, 'Why Most Published Research Findings Are False' 2(8) PloS Medicine E124 ${ }^{80}$ See Tom E Hardwicke et al, 'Calibrating the Scientific Ecosystem Through Meta-Research' (2020) 7 Annual Review of Statistics and its Application 11.
} 
refers to scientists withholding the aspects of their studies that did not support their hypotheses (e.g., drug outcomes that did not work) such that what is reported miscontrues their findings. ${ }^{81}$

By many accounts, selective reporting is rampant and a major cause of problems with reproducibility. One survey of 1,576 researchers found that $90 \%$ believe there is at least a slight reproducibility crisis in science (and 52\% said it was a significant crisis). The most commonly reported contributing factor was selective reporting, as indicated by over $90 \%$ of respondents. ${ }^{82}$ Further, in another survey of 2,000 psychologists, over $63 \%$ self-reported engaging in selective reporting; these voluntary (albeit anonymous) accounts indicate the true rate of selective reporting is likely even higher. ${ }^{83}$ Empirical investigations of the literature reach similar conclusions; for instance, one study analysed 53 published social science experiments and found that $80 \%$ of these did not report all experimental conditions and outcomes. ${ }^{84}$ More recently, Cairo and colleagues found that almost half of the 256 published social science studies analysed included some form of selective reporting. ${ }^{85}$ Thus, whilst in some sense researchers are becoming increasingly aware of these issues and limitations, simultaneously, the prevalence of these questionable research practices raises concerns about the credibility of science. It is of interest to us then, to consider whether lay people are aware of these problems.

\footnotetext{
${ }^{81}$ Joseph P Simmons, Leif D Nelson and Uri Simonsohn, 'False-Positive Psychology: Undisclosed Flexibility in Data Collection and Analysis Allows Presenting Anything as Significant' (2011) 22(11) Psychological Science 1359.

${ }^{82}$ Monya Baker, 'Is There a Reproducibility Crisis? A Nature Survey Lifts the Lid on How Researchers View the Crisis Rocking Science and What They Think Will Help' (2016) 533 Nature 452.

${ }^{83}$ Leslie K John, George Loewenstein, and Drazen Prelec, 'Measuring the prevalence of questionable research practices with incentives for truth telling' (2012) 23(5) Psychological science 23.5 524. Other fields have found similar results: Hannah Fraser et al, 'Questionable Research Practices in Ecology and Evolution' (2018) 13(7) PLoS $O N E$ e0200303; Franca Agnoli et al, 'Questionable research practices among italian research psychologists' (2017) 12(3) PLoS ONE e0172792; Jason M Chin et al, 'Questionable Research Practices and Open Science in Quantitative Criminology' (accepted) Journal of Quantitative Criminology. Matthew C Makel et al, 'Both questionable and open research practices are prevalent in education research' (2021) Educational Researcher.

${ }^{84}$ Annie Franco, Neil Malhotra, and Gabor Simonovits, 'Underreporting in political science survey experiments: Comparing questionnaires to published results' (2015) 23(2) Political Analysis 306.

${ }^{85}$ Athena H Cairo, et al, 'Gray (literature) matters: Evidence of selective hypothesis reporting in social psychological research’ (2020) 46(9) Personality and Social Psychology Bulletin 1344.
} 
Recent studies indicate lay people are unaware of the extent to which science is plagued by these problematic practices and reproducibility issues. ${ }^{86}$ One study, for instance, found that out of 406 US adults, 71\% deemed selective reporting morally unacceptable, with 37\% indicating this practice should be criminalised ${ }^{87}$ It stands to reason that most of these respondents would be surprised to find that the act they classified as warranting criminal sanctions is actually widespread. Similarly, a recent pilot study with 303 lay respondents found that, when asked to what extent they endorse research practices such as selective reporting, over $80 \%$ of respondents strongly disapproved. ${ }^{88}$ This represents a substantial disconnect between practice and public perceptions. Beyond selective reporting, we expect that the public would generally be surprised about how widespread other practices are, such as dropping 'outliers' from a research study after seeing their effect on the data and rounding off statistics in a favourable way. ${ }^{89}$

These studies about the public's understanding of the scientific process underscore just how prejudicial scientific evidence can be when its flaws and uncertainties are not intuitive or understood by the public. In other words, this work provides a fuller understanding of a prejudice courts already recognize, a 'white coat effect' 90 whereby lay factfinders place more weight on scientific and technical evidence than is warranted.${ }^{91}$ It also suggests that courts should continue

\footnotetext{
${ }^{86}$ Farid Anvari and Daniël Lakens, 'The replicability crisis and public trust in psychological science' (2018) 3(3) Comprehensive Results in Social Psychology 266; Niels G Mede, et al, 'The "replication crisis" in the public eye: Germans' awareness and perceptions of the (ir) reproducibility of scientific research' (2021) 30(1) Public Understanding of Science 91.

87 Justin T Pickett and Sean Patrick Roche, 'Questionable, objectionable or criminal? Public opinion on data fraud and selective reporting in science' (2018) 24(1) Science and Engineering Ethics 151.

88 Julia Bottesini and Simine Vazire, 'Do Participants Care If We p-Hack Their Data?' (Poster Presentation at Metascience 2019) <https://osf.io/3f9ba/>.

${ }^{89}$ See sources at note 83 .

${ }^{90}$ Dirani (n 55) [112]; Morgan (n 19) [146],

${ }^{91}$ Mallard v The Queen [2003] WASCA 296 [295].
} 
to recognise the white coat effect - perhaps more willingly than they do now - because foundational lay misunderstandings about how the scientific process operate are widespread.

This background on lay-scientific misunderstandings also sets the stage as we drill down into more specific ways in which expertise can mislead the factfinder: the CSI Effect and stereotypes about expert witnesses - both of which may be exacerbated by conditions that prevent jurors from attending to the substance of the evidence, instead prompting them to attend to the peripheral characteristics of the expert.

\section{The CSI effect(s)}

The term 'CSI effect' is problematic because it encompasses a variety of effects with varying levels of empirical support (from strong to almost nil), which are not always clearly delineated by researchers. ${ }^{92}$ In fact, in the recent Xie $v$ The Queen case, ${ }^{93}$ a judge appeared to conflate two meanings of the CSI effect and gave the jury a direction based on that misunderstanding. We will try to provide some clarity about the CSI effect in this section (and see Table 2), focusing on the version that may present an unfair prejudice in some cases (sometimes called the 'defendant's effect' in the research literature).

The original hypothesis for the CSI effect was that the rise of CSI and fictional forensic science television shows placed a burden on prosecutors because jurors would expect a high degree of sophisticated forensic evidence. ${ }^{94}$ This has been called the 'prosecutor's effect' and finds most of its support in anecdotes of prosecutors who say that CSI programming has made

\footnotetext{
92 Unfortunately, not all researchers explain what CSI Effect they are attempting to measure. However, for useful reviews that do make these distinctions, see Podlas (n 57); Simon A Cole and Rachel Dioso-Villa, 'CSI and Its Effects: Media, Juries, and the Burden of Proof' (2006) 41 New England Law Review 435; Jane GoodmanDelahunty and David Tait, 'DNA and the Changing Face of Justice' (2009) 38(1) Australian Journal of Forensic Sciences 97.

93 [2021] NSWCCA 1 ('Xie’).

${ }^{94}$ Cole and Dioso-Villa (n 92) 447 call this the 'purest version' of the CSI Effect.
} 
their work harder because it has raised public expectations. ${ }^{95}$ Reliance on these self-reports is problematic because they may be self-serving and because prosecutors' perceptions are not based on systematic observation. ${ }^{96}$ Indeed, most studies have failed to find support for the prosecutor's effect. For instance, one meta-analysis (a statistical technique of synthesising the findings of studies on the same topic) concluded the research 'strongly suggests that the CSI effect does not exist' (referring to the prosecutor's effect). ${ }^{97}$ Two unsystematic reviews came to the same conclusion. $^{98}$

In contrast to those null results for the prosecutor's effect, there is stronger evidence for the 'defendant's effect'. With the defendant's effect, the depiction of CSI in popular culture disadvantages defendants in that 'the extremely positive portrayal of forensic scientists on CSI and similar shows is likely to enhance the credibility of forensic scientists' ${ }^{99}$ This flavour of the CSI effect is a forensic science-specific version of the first prejudice we described: overtrusting science and being unaware of various weaknesses in its processes and structures. ${ }^{100}$ The defendant's effect is also consistent with research demonstrating that jurors find forensic

\footnotetext{
${ }^{95}$ Podlas (n 57). Jurors in an Australian study also noted an absence of forensic evidence as a reason they were sceptical of the production's case: Jacqueline Horan and Jane Goodman-Delahunty, 'Expert evidence to counteract jury misconceptions about consent in sexual assault cases: Failures and lessons learned' (2020) 43(2) University of New South Wales Law Journal 707.

${ }^{96}$ Podlas (n 57) puts a finer point on it: 'In the same way that a survey of six-year-olds finding that they believe in Santa Claus is not proof that Santa exists, a survey of attorneys finding that they believe in a CSI Effect is not proof that a CSI Effect exists. Simply, the belief in a CSI Effect is not evidence of a CSI Effect'

${ }^{97}$ Gordon Eatley, Harry H Hueston, and Keith Price, 'A Meta-Analysis of the CSI Effect: The Impact of Popular Media on Jurors' Perception of Forensic Evidence' (2016) 5(2) Politics, Bureaucracy \& Justice 1.

${ }_{98}$ Podlas (n 57); Chin and Workewych (n 57).

${ }_{99}$ Cole and Dioso-Villa (n 92) 449; Podlas: ‘...the overwhelming majority of studies have found no evidence of a CSI Effect that negatively impacts the prosecution or that forensic crime shows are correlated with either acquittals or distortions in the deliberative process. To the contrary, results suggest that to the extent that CSI impacts juror attitudes, it does so in a way that benefits the prosecution'.

100 The New South Wales Court of Criminal Appeal in Xie (n 93) [458] rightly equated CSI Effect to a general white coat effect.
} 
evidence especially persuasive and reliable as compared to other forms of evidence, ${ }^{101}$ and that its presence and absence can have a significant effect on verdicts. ${ }^{102}$

[Table 2 about here]

Other CSI effects have been described in the literature and relate to CSI programming increasing interest in studying forensic science (the 'professor's version') and providing criminals with new ideas for evading the police (the 'police chief's version'). ${ }^{103}$ These are not relevant to factfinding for the purposes of this article, but they do demonstrate the general nebulousness of the terminology in this field.

Given this confusing state of the literature, and that some articles treat the CSI effect as a monolith (The New South Wales Law Reform Commission's report on jury directions fell prey to this), ${ }^{104}$ it is perhaps not surprising that courts would struggle as well. Fortunately, most decisions we are aware of seem to be referring to the defendant's effect when they refer to a CSI

101 Cora Y T Hui and T Wing Lo, 'Examination of the "CSI Effect" on Perceptions of Scientific and Testimonial Evidence in a Hong Kong Chinese Sample’ (2017) 61(7) International Journal of Offender Therapy and Comparative Criminology 819 finding participants viewed forensic evidence as more reliable than forms of testimonial evidence.

102 Kimberly Schweitzer and Narina Nuñez, 'What Evidence Matters to Jurors? The Prevalence and Importance of Different Homicide Trial Evidence to Mock Jurors' (2018) 25(3) Psychiatry, Psychology and Law 437 finding mock jurors ranked forensic evidence as most important when coming to their verdicts; jury simulation studies that have manipulated the presence of different types of evidence (e.g., eyewitness evidence, fingerprint evidence, DNA evidence) show that when forensic evidence is presented, guilty verdicts increase compared to when eyewitness evidence is presented: Shichun Ling, Jacob Kaplan, and Colleen M Berryessa, 'The importance of forensic evidence for decisions on criminal guilt' (2021) 61(2) Science \& Justice; John M Pearson et al, 'Modelling the effects of crime type and evidence on judgments about guilt' (2018) 2(11) Nature Human Behaviour 856.; Paul Skonick and Jerry I Shaw, 'Skolnick, Paul, and Jerry I. Shaw. "A comparison of eyewitness and physical evidence on mock-juror decision making' (2001) 28(5) Criminal Justice and Behavior 614; Skolnik \& Shaw, 2001; Evelyn M Maeder, Logan A Ewanation, and Jordan Monnick, 'Jurors' Perceptions of Evidence: The Relative Influence of DNA and Eyewitness Testimony when Presented by Opposing Parties’ (2017) 32(1) Journal of Police and Criminal Psychology 1.

103 Cole and Dioso-Villa (n 92) 451-2.

104 New South Wales Law Reform Commission, Jury directions (Report No 136, November 2012) 80-81 ('NSWLRC 136'). 
effect without explicitly saying so. ${ }^{105}$ However, we draw attention to one 2021 decision that may serve as a cautionary tale.

In Xie v The Queen, a stain found at the accused's residence was particularly relevant because it contained DNA linking the accused to multiple killings. ${ }^{106}$ However, it also contained DNA of someone not in the country, indicating contamination. As a result, the integrity of the crime scene and how the evidence was gathered was particularly relevant. Against this backdrop, the trial judge gave a direction that seemed to fundamentally misunderstand the research behind the CSI Effect: 107

... when you are considering whether the Crown has proved its case beyond reasonable doubt, you should not penalise the Crown if you think there are questions left unanswered by the crime scene analysts [...] In giving you that direction, which has come to be styled as the 'CSI direction', as you would understand to be for obvious reasons, it is not something, ladies and gentlemen, that I have invented. It is a direction that I have determined to give in this trial, informed by academically-based research of exiting jurors from other trials in this State, other States of the Commonwealth and other parts of the world where, under the supervision of a disciplined academic analysis, informed researchers endeavoured to determine, from exiting juror polls, whether the CSI effect has in some way, influenced their verdict.

While this direction is worrisome from the principled perspective that it may lower the burden of proof and infringe on the presumption of innocence, ${ }^{108}$ in the context of this article, we emphasise that it is discordant with the scientific consensus on the CSI Effect. If anything, research indicates that the jury would place too mисh weight on the forensic evidence and this

\footnotetext{
105 Wise (n 58) [70]; Ramaros (n 60) [46]; Paulino (n 60) [24].

106 Xie (n 93).

107 Ibid [449] [emphasis added]; we speculate the judge had referred to the New South Wales Law Reform Commission Report on jury directions when learning about the CSI Effect.

108 Chin and Workewych (n 57).
} 
type of direction would only heighten that prejudice. Moreover, despite the judge's comments, since around 2010 (the Xie trial occurred in 2017), US jurisdictions began abandoning these types of directions in light of the research failing to support their foundation. ${ }^{109}$ The New South Wales Court of Criminal Appeal did not order a retrial on the basis of the direction in Xie, but did express confusion about what sources the trial judge was drawing from. ${ }^{110}$ Still, the fact that such a fundamental (but understandable) misunderstanding exists suggests the need for clarity about the CSI effect. Moreover, reliance on a dubious social scientific finding would seem to violate the rules against judicial notice (judges relying on any evidence that is not common sense and not adduced by a party). ${ }^{111}$

\section{[Table 2 about here]}

Expert evidence stereotypes: gender, status, and experience

Beyond the expectation that forensic evidence is reliable and credible, ${ }^{112}$ researchers have studied several other ways in which the characteristics of the expert may affect the way that their evidence is received. This falls under a broad and well-established area of research demonstrating that people, including judges and jurors, rely on heuristics (i.e., mental shortcuts) and stereotypes that can affect their reasoning in ways they do not realise. ${ }^{113}$ In short, these stereotypes can lead the factfinder to evaluate the witness's evidence based on legally irrelevant

\footnotetext{
109 Ibid.

110 "The basis of her Honour's references to a "CSI effect" is not apparent. Nor is it apparent what her Honour was referring to when saying the concept was familiar "for judges working in this division" and that she had determined to give the direction, having been "informed by academically-based research of exiting jurors".': Xie (n 93) [459].

111 See, e.g., UEL (n 1) s 144; Aytugrul (n 61) [20]-[22], [68]-[74].

112 Podlas (n 57) couches the CSI Effect as a heuristic; see also Tom R Tyler, 'Viewing CSI and the threshold of guilt: Managing truth and justice in reality and fiction' (2005) 115 Yale Law Journal 1050.

113 See Kai Ruggeri, 'Replicating patterns of prospect theory for decision under risk' (202) 4 Nature Human Behaviour 622.
} 
factors. We will discuss stereotypes related to the gender of the expert witness, their status (i.e., eminence), and their experience.

Stereotypes about whether the field of expertise is either male- or female-dominated can influence perceptions of experts. In one study, for example, participants read about a case of 'battered woman syndrome' where the defendant was a woman who claimed to have killed her husband in the act of self-defence. ${ }^{114}$ Participants read the testimony of either a male or female expert who provided information on battered woman syndrome. The researchers found that when the expert was female, participants were less likely to render a verdict of guilty, more likely to believe the defendant, considered the defendant less responsible, and rated the husband as more responsible, as compared to when the expert was male. Other studies find similar results, suggesting that the relationship between gender and content domain influences perceptions of expert witnesses and subsequent decision making. ${ }^{115}$

As with gender, status bias occurs when someone's rank or prominence in a field unduly affects our evaluation of the quality of what they are saying or doing. ${ }^{116}$ We are not aware of any empirical demonstrations of status bias in legal settings. However, in sports, baseball umpires are more likely to favourably misjudge pitches (calling them strikes when they are balls) of highstatus pitchers as compared to their low-status counterparts. ${ }^{117}$ Status bias is more pronounced

\footnotetext{
${ }^{114}$ Regina Schuller and Janice Cripps, 'Expert evidence pertaining to battered women: The impact of gender of expert and timing of testimony' (1998) 22(1) Law and Human Behavior 17. Reflecting that breadth of the phenomenon, the term 'battered spouse syndrome' may be more appropriate: Osland v The Queen [1998] HCA 75 [159].

115 Blake M McKimmie et al, 'The impact of gender-role congruence on the persuasiveness of expert testimony' (2019) 38(2) University of Queensland Law Journal 279; the general relationship (not taking into account whether or not the field is gendered) between expert witness gender and how their message is perceived is complicated: For a review, see Tess M S Neal, 'Women as Expert Witnesses: A Review of the Literature' (2014) 32(2) Behavioral Sciences and the Law 164.

116 Jerry W Kim and Brayden G King, 'Seeing Stars: Matthew Effects and Status Bias in Major League Baseball Umpiring' (2014) 60(11) Management Science 2619.

117 Ibid.
} 
with pitches on the borderline, which indicates that status is taken into greater account when quality is difficult to judge (see below under central and peripheral route processing). ${ }^{118}$

In research more relevant to expert evidence, researchers find that scientific peer reviewers in academic journals tend to give more favourable reviews to high-status authors. ${ }^{119}$ These studies control for the possibility of high-status authors simply producing better work by comparing reviews in which the reviewer knows the identity of the author versus when they do not. The status effect is more pronounced when the reviewer knows that the author is high-status, which suggests bias. ${ }^{120}$ Status bias has also been linked to the reproducibility crisis in science discussed above, in that many of the factors that increase one's status in science are correlated with low-quality work: ${ }^{121}$

First, eminence does not appear to be a predictor of producing more credible (e.g., replicable) research $[\ldots]$ What we have learned from the metascience movement in the field over the past decade is that the most efficient strategies for optimizing the metrics that lead to fame are strategies that run counter to the most efficient strategies for producing research that is credible, and useful outside of our disciplinary bubble.

The final stereotype we will discuss may be the most surprising to the reader: an expert's years of experience. The years of experience an expert has in their work can be misleading in some circumstances. ${ }^{122}$ As Imwinkelried has noted, quantity of experience is not always a gauge

118 Ibid; See generally Amos Tversky and Daniel Kahneman, 'Judgment under uncertainty: Heuristics and biases' (1974) 185(4157) Science 1124.

${ }^{119}$ Kanu Okike, 'Single-blind vs double-blind peer review in the setting of author prestige' (2016) 316(12) JAMA 1315; Andrew Tomkins, Min Zhang, and William D Heavlin, 'Reviewer bias in single- versus double-blind peer review' (2017) 114(48) PNAS 12708.

${ }^{120}$ Status bias likely underpins a 'Matthew Effect' in science, whereby high-status researchers receive preferential treatment thereby exaggerating their advantage: Robert K Merton, 'The Matthew effect in science' (1968) 159(3810) Science 56.

${ }^{121}$ Neil Lewis Jr and Jonathan Wai, 'Communicating what we know and what isn't so: Science communication in psychology' (2021) Perspectives on Psychological Science [citations omitted]; see also Simine Vazire, 'Our obsession with eminence warps research' (2017) 547 Nature 7.

${ }^{122}$ Martire and Edmond (n 6) 975-6. 
of quality, and this can lead to overvaluation: 'If the jury heard only the reference to the quantum of experience during the witness's direct examination, there would arguably be such a risk [of overvaluation]. At first blush, numbers such as 10 years or 1,000 tests sound quite impressive.' ${ }^{123}$ There are many reasons why highly experienced experts might perform below what one would expect of experienced people. For instance, working in environments where there is little or no feedback such that the expert cannot easily know when they are right or wrong is linked to experience that outpaces quality. ${ }^{124}$ Similarly, some skills are difficult to learn and derive heavily from natural talent. This appears to be the case with facial recognition. ${ }^{125}$ Research in the field of facial comparison (e.g., those who compare images of faces in CCTV footage to an image of a suspect) finds that many highly experienced professionals perform no better than undergraduate students and considerably worse than individuals with an innate talent for face comparison (sometimes called super recognisers). ${ }^{126}$

Unlike the CSI Effect, with its catchy name and association with a popular television show, these other expert evidence stereotypes (e.g., the high status expert, the high experience expert) do not seem to be well-recognised in case law. ${ }^{127}$ In one useful demonstration however, a Victorian trial court excluded an expert in educational research, in part, because of how his seemingly impressive credentials (e.g., $\mathrm{PhD}$, former dean), might have misled the jurors: 'His extensive qualifications give rise to a danger that his evidence would, in the words of Gleeson CJ

\footnotetext{
${ }^{123}$ Edward J Imwinkelried, 'The Shifting Battleground over the Admissibility of Experientially Based Expert Testimony: How Far May Experts Go in Elaborating on the Personal Experience Supposedly Validating Their Methodology, (202) 68(1) Drake Law Review 43, 66.

${ }^{124}$ Martire and Edmond (n 6) 980-2.

${ }^{125} \mathrm{P}$ Jonathon Phillips et al, 'Face recognition accuracy of forensic examiners, superrecognizers, and face recognition algorithms' (2018) 115(24) PNAS 6171.

126 Ibid.

${ }^{127}$ That is, beyond references to a general white coat effect and the authority of science: Morgan (n 19) [146]; HG (n 46) [44].
} 
above, have "a spurious appearance of authority". ${ }^{128}$ Here, the court was developing the notion of a general white coat effect by explaining how, on the facts before it, impressive but largely irrelevant postnominals contributed to that white coat effect. The seeming rarity of such reasoning is unfortunate because the confluence of several expert witness stereotypes is likely prejudicial in many cases. For instance, an expert with prestigious degrees, awards, and many years of experience applying weak methods could be highly misleading to the factfinder, and produce a miscarriage of justice. ${ }^{129}$ Courts should consider such signifiers as prejudicial when they are not accompanied by evidence of demonstrable reliability.

Peripheral route processing

When are these stereotypes and heuristics more likely to be relied upon? To address this, we turn to research on the 'elaboration likelihood model'. This model was originally used to understand the effectiveness of persuasive messages, ${ }^{130}$ and its principles have since been applied to explain how expert witness testimony is evaluated by factfinders. ${ }^{131}$

The elaboration likelihood model posits that there are two processes by which jurors evaluate the testimony of an expert. One is the central (in other words, systematic) processing route - the non-prejudicial route - whereby jurors effortfully scrutinize the substance of the expert's evidence. Jurors are most likely to do this when they find the evidence personally relevant or important, when they are motivated, and when they have the time and cognitive

\footnotetext{
${ }^{128}$ Rees (n 54) [50].

${ }^{129}$ See Jason M Chin, Bethany Growns, and David T Mellor, 'Improving Expert Evidence: The Role of Open Science and Transparency’ (2019) 52(2) Ottawa Law Review 365, 390-6.

130 Richard E Petty and John T Cacioppo, The elaboration likelihood model of persuasion (Springer, 1984); Richard E Petty and John T Cacioppo, 'The effects of involvement on responses to argument quantity and quality: Central and peripheral routes to persuasion' (1984) 46(1) Journal of Personality and Social Psychology 69.

${ }_{131}$ McKimmie et al (n 115) 281-3; Ian Freckelton QC et al, Expert Evidence and Criminal Jury Trials (Oxford, 2016) Chapter 5.
} 
ability to comprehend the expert's message. ${ }^{132}$ However, when these criteria for central route processing are not met, jurors will be more likely to use the other route, which relies on peripheral cues, including reliance on heuristics and stereotypes.

Given that experts often provide technical and specialised evidence, ${ }^{133}$ it is especially concerning that difficult-to-understand evidence can trigger peripheral route processing of expert evidence. ${ }^{134}$ Recall, for instance, that was it was the difficult and unclear pitches for which umpires wound up relying on the pitcher's status to determine whether they were balls or strikes. On the other hand, preliminary research suggests the effect of peripheral cues may have little or no effect when jurors are given clear statements of the expert evidence's strengths and weaknesses. ${ }^{135}$

The existing unfair prejudice jurisprudence does sometimes take into account the complexity of evidence by recognising that prejudices related to expert evidence are mitigated when evidence is straightforward and easy to understand. ${ }^{136}$ For instance, in Aytugrul v The Queen, the High Court considered whether the way in which statistics were presented to jurors could mislead them and thus raise an unfair prejudice. ${ }^{137}$ In fact, the court was presented with

\footnotetext{
${ }^{132}$ Regina A Schuller, Deborah Terry, and Blake McKimmie, 'The Impact of Expert Testimony on Jurors' Decisions: Gender of the Expert and Testimony Complexity' (2005) 35(6) Journal of Applied Social Psychology 1266; Freckelton et al (n 131) Chapter 5.

${ }^{133}$ Helena Likwornik, Jason Chin, and Maya Bielinski, 'The diverging dictionaries of science and law' (2018) 22(1) The International Journal of Evidence \& Proof 30; A survey of Australian legal professionals has shown that poorly articulated, jargon-filled expert testimony are commonly considered to be hallmark features of poor oral testimony: Elena Gianvanni and Stefanie J Sharman, 'Legal Representatives' Opinions regarding Psychologists Engaging in Expert Witness Services in Australian Courts and Tribunals' (2017) 24(2) Psychiatry, Psychology and Law 223. ${ }^{134}$ Schuller, Terry, and McKimmie (n 132); Joel Cooper and Isaac M Neuhaus, 'The "hired gun" effect: Assessing the effect of pay, frequency of testifying, and credentials on the perception of expert testimony' (2000) 24(2) Law and Human Behavior 149.

${ }^{135}$ Mariam Younan and Kristy A Martire, What Makes an Expert Persuasive? Examining the Influence of Relevant and Superficial Cues on Jurors' Evaluation of Forensic Expert Credibility and Evidence Quality (Conference presentation, Virtual Society of Applied Memory and Cognition Conference, Online, 21-23 July 2021).

${ }^{136}$ Dirani (n 55) [128]: "I do not consider there is any real risk of the so-called "white coat effect" having application in this case. This is not a case involving complex scientific or technical issues. The concepts being discussed may be understood by the jury.'; Aytugrul (n 61) [31].

${ }^{137}$ Aytugrul (n 61) [30]-[31], [34].
} 
psychological studies supporting the notion that laypeople tend to overvalue some statistics. ${ }^{138}$ However, the court disregarded these studies because they were not presented through an expert (this raises the question of why it is acceptable to avoid adversarial processes when, for instance, trial judges take notice of academic research on the CSI Effect). ${ }^{139}$ In any case, the majority found that while the statistics may have been misleading, that was mitigated by the fact that the expert had clearly explained the underlying concepts. ${ }^{140}$ A concurring judge (Heydon J) went so far as to say that complexity was mitigated by the fact that juries are likely to have one mathematically inclined person to mitigate this complexity for the others: 'The field is arcane. But any criminal jury of 12 is likely to contain at least one juror capable of realising, and demonstrating to the other jurors, that the frequency estimate was the same as the exclusion percentage.' ${ }^{141}$ This is a baseless and troubling statement, but, as we will develop in Parts IV and $\mathrm{V}$, we agree that it is crucial that the strengths and weaknesses of expert evidence be clearly presented to the jury.

\section{$\underline{\text { An absence of severe tests }}$}

A claim is severely tested to the extent that it has been subjected to and passes a test that probably would have found flaws, were they present. You may be surprised to learn that many methods advocated by experts do not stand up to severe scrutiny, and are even in tension with successful strategies for blocking or accounting for cherry picking and selective reporting. ${ }^{142}$

In many fields, it is not just that lay people may grant claims more probative value than they deserve, but that the probative value of many claims is difficult or impossible to assess. This feature of some fields of expertise raises the prejudice of evidence being untestable or difficult to

\footnotetext{
138 Ibid [20].

139 Ibid [20]-[22].

140 Ibid [34].

${ }^{141}$ Ibid [75] (Heydon J).

142 Deborah G Mayo, Statistical Inference as Severe Testing (Cambridge, 2018) xii.
} 
test, which puts the party seeking to challenge the evidence at an unfair disadvantage. ${ }^{143}$ This lack of testing and testability is summed up in the above epigraph explaining the reproducibility crisis through a lack of severe testing that would expose flaws in knowledge. Severe testing is a useful touchstone for the remaining four prejudices of expert evidence. In other words, can the adverse party find the information they need to test the proffered expert? Does such information exist to begin with? And, assuming it is theoretically possible to severely test the evidence, can we reasonably expect that to occur given the adversarial imbalances we discuss?

As Mayo said in the above epigraph, many fields of expertise have not supplied critics with the ammunition they need to severely test their claims. Severe testing is not possible when researchers do not share their data (as most do not in many fields) ${ }^{144}$ such that peer reviewers and others can spot errors: 'Transparent documentation and data come with higher error visibility, and the flexibility to avoid acknowledging mistakes is lost.' ${ }^{245}$ The same is true when researchers selectively report conditions and outcomes that work, do not report results that do not fit the main hypothesis (see selective reporting, above), ${ }^{146}$ and exclude outliers data points after observing their effect on the data (again, a widespread practice). ${ }^{147}$

These failures of severity are likely even worse in forensic science, a frequent player in the legal system. In a widely influential report, the National Academy of Sciences found that many forensic scientific fields had not even begun to test their claims, let alone severely: 'In a number of forensic science disciplines, forensic science professionals have yet to establish either

\footnotetext{
143 See the sources at note 52 .

144 Tom E Hardwicke et al, 'An empirical assessment of transparency and reproducibility-related research practices in the social sciences (2014-2017)’ (2020) 7(2) Royal Society Open Science 190806.

145 Christopher Allen and David M A Mehler, 'Open science challenges, benefits and tips in early career and beyond' (2019) 17(5) PloS Biology e3000246, 3.

146 Simmons, Nelson, and Simonsohn (n 81).

147 See sources at note 83 .
} 
the validity of their approach or the accuracy of their conclusions...' ${ }^{148}$ To this day, forensic science journals - where such validation studies would likely be published - do not impose even the barest severity requirements, like authors providing data with their reports. ${ }^{149}$ As a result, there should be serious scrutiny as to whether claims from forensic science and other fields raise an unfair prejudice because the information required for the adverse party to test them is not available (and they have not been tested previously through review by a critical community). ${ }^{150}$ Black box experts

Forensic feature comparison practices, which are 'among the oldest and most commonly employed of forensic methods' ${ }^{151}$ raise additional issues that often limit parties' ability to test them. These practices involve, for instance, comparing the features of a latent fingerprint, such as one found at a crime scene, to that of the accused. One prejudice of many of these practices is that they rely on the subjective, unconscious judgment of human examiners. ${ }^{152}$ In other words, the actual analysis - the application of purported specialised knowledge to the case facts - relies on unconscious visual processing that experts cannot verbally articulate (i.e., it occurs in a black box). ${ }^{153}$ With fingerprint analysis, for example, there is no specific number of similarities that constitute an identification that examiners can verbally report about when giving their evidence

\footnotetext{
${ }^{148}$ National Research Council, 'Strengthening Forensic Science in the United States: A Path Forward' (National Academies Press, 2009) 53.

149 Jason M Chin, Gianni Ribeiro \& Alicia Reardon, 'Open Forensic Science' (2019) 6(1) The Journal of Law and the Biosciences 255 .

${ }^{150}$ Under $U E L$ jurisprudence, we saw that when evidence cannot be exposed to examination by the adverse party, that may rise to the level of unfair prejudice. In the expert context, this includes the failure to tender key reports or another expert who can speak to how the testing was conducted: Kyluk (n 39); Sing (n 69).

151 Thomas D Albright, 'The US Department of Justice stumbles on visual perception' (2021) 18(24) PNAS e2102702118.

152 The President's Council of Advisors on Science and Technology, 'Forensic Science in Criminal Courts: Ensuring Scientific Validity of Feature-Comparison Methods' (Executive Office of the President, 2016) 5-6 ('PCAST Report').

153 Jason M Chin and William E Crozier, 'Rethinking the Ken Through the Lens of Psychological Science' (2018) 55:3 Osgoode Hall Law Journal 625, 632.
} 
(although previous iterations of the practice required this). ${ }^{154}$ Rather, it's an intuitive process, and one that some fingerprint examiners do get good at making (and that others lag - knowledge we would not have without severe testing). ${ }^{155}$

Unconscious judgment is also susceptible to a variety of cognitive biases that the expert cannot verbally report on. ${ }^{156}$ These biases range from 'contextual bias' ${ }^{157}$ resulting from exposure to irrelevant, perhaps emotional case information, to what are known as 'adversarial biases', ${ }^{158}$ flowing from experts being appointed and paid by parties to the litigation. For instance, in one study, clinical psychologists and psychiatrists who were randomly assigned to believe they were appointed by the defence or prosecution came to different conclusions when using well-established risk assessment tools. ${ }^{159}$ Expert witnesses (and humans) tend to not be aware of the operation of these biases and discount them when expressly asked. ${ }^{160}$ These biases cannot be willed away. Rather, the best recourse is to avoid exposure to biasing information, a safeguard many experts do not rely on. ${ }^{161}$

The unconscious and subjective character of black box expertise can present significant unfair prejudice as has been defined by the relevant case law. Examiners' inability to introspect about how they have come to their decisions makes their opinion insusceptible to a 'full and fair

\footnotetext{
154 Gary Edmond, 'Latent science: A history of challenges to fingerprint evidence in Australia' (2019) 38(2) University of Queensland Law Journal 309-10; Searston and Chin (n 45) 241.

155 PCAST Report (n 152) 101-2; Jason M Tangen, Matthew B Thompson, and Duncan J McCarthy, 'Identifying fingerprint expertise' (2011) 22(8) Psychological Science 995.

156 PCAST Report (n 152) 98-9; Jason M Chin, Michael Lutsky, and Itiel E Dror 'The biases of experts: An empirical analysis of expert witness challenges' (2019) 42(4) Manitoba Law Journal 21, 24-30.

157 Gary Edmond et al, 'Contextual Bias and Cross-contamination in the Forensic Sciences: the Corrosive Implications for Investigations, Plea Bargains, Trials and Appeals' (2014) 14(1) Law, Probability \& Risk 1. 158 Bernstein (n 5).

159 Daniel C Murrie et al, 'Are Forensic Experts Biased by the Side That Retained Them?' (2013) 24(10) Psychological Science 1889.

160 Jeff Kukucka et al, 'Cognitive Bias and Blindness: A Global Survey of Forensic Science Examiners' (2017) 6(4) Journal of Applied Research in Memory and Cognition 452; David Dunning, Chip Heath and Jerry M Suls, 'Flawed Self-Assessment: Implications for Health, Education, and the Workplace' (2004) 5(3) Psychological Science in the Public Interest 69.

161 PCAST Report (n 152) 89-90.
} 
opportunity to test $[\ldots]$ in cross-examination'162 Their opinions' 'weaknesses and strengths' cannot be 'well understood' through traditional adversarial means. ${ }^{163}$ Similarly, while experts would surely want to be helpful and candid about any threats to the integrity of their evidence, they are incapable of explaining the effect of any unconscious biases on their opinion and are likely to discount any such effects. ${ }^{164}$ This final characteristic of black box expertise analogises to the prejudice in $A S I C v$ Rich, in which 'the risk that the expert might have unwittingly relied on, been influenced by or taken into account material that has not been identified as part of the factual basis' contributed to prejudice identified by the court. ${ }^{165}$

$\underline{\text { Adversarial imbalance }}$

There are also practical constraints on adversarial testing that contribute to prejudice in criminal contexts. In particular, while adversarial systems hinge on the idea that the parties will vigorously uncover the flaws in each other's evidence, this often does not happen. In the criminal context, US researchers have noted substantial adversarial imbalance such that the defence rarely challenges the prosecution's experts or obtains experts of their own. ${ }^{166}$ For instance, in a review of 137 trial transcripts of exonerees who had been imprisoned based on forensic science evidence, the authors found that only 19 defendants had retained experts. ${ }^{167}$ The defence also rarely effectively cross-examined the forensic expert or addressed the evidence's shortcomings

\footnotetext{
${ }^{162}$ La Trobe (n 52) [66].

163 Charan (n 75) [507].

${ }^{164}$ Kukucka et al (n 160).

165 Australian Securities and Investments Commission (ASIC) v Rich [2005] NSWSC 149 [377] ('Rich'). The Court in Rich treated these issues with the factual basis of the opinion as relevant to the exclusionary discretion (weighing probative value and unfair prejudice in section 135, and did not take a stand on the existence of the basis rule: see [296]-[325]. As noted in Part II, more recent decisions have been firmer in their rejection of the basis rule, see Dasreef (n 42).

166 Keith A Findley, 'Innocents at Risk: Adversary Imbalance, Forensic Science, and the Search for Truth' (2008) 38(3) Seton Hall Law Review 893; Garrett and Neufeld (n 5); on adversarial imbalance in expert witness contexts generally, see David Hamer and Gary Edmond, 'Forensic Science Evidence, Wrongful Convictions and Adversarial Process' (2019) 38(2) University of Queensland Law Journal 185.

167 Garrett and Neufeld (n 5) 34.
} 
in their closing. ${ }^{168}$ In Australia, Freckelton and colleagues studied 55 trials from 2011-12, finding that the defence retained an expert in only about a third of those trials and in the majority of cases they looked at, 'the prosecution called a few experts and the defence called none.' 169 These findings flow from systemic issues within the legal system. The defence often lacks the funds to retain an expert, who could both provide testimony and consult with the defence lawyer. Further, lawyers cannot be expected to have training and education in the fields of expertise they are confronted with. ${ }^{170}$

Systemic, practical constraints on adversarial testing represent a source of unfair prejudice, but one that courts have mostly failed to recognise. In other words, while courts acknowledge that some constraints on testing (like complexity and the unavailability of a witness) contribute to prejudice, they do not see fundamental imbalances in the legal system the same way (although we located one US decision that engaged in this reasoning). ${ }^{171}$ This blind spot contributes to injustice because a systemic limit on adversarial testing has the same consequences as those which have been accepted in existing jurisprudence: expert evidence makes its way to the factfinder without any mechanisms to reveal its weaknesses. Under such conditions, nothing approaching severe testing can be achieved.

\section{Adversarially untested}

Heightening the unfair prejudice from adversarial imbalance is that some courts think that the mere fact that a type of expert evidence was admitted in the past means that it has passed

\footnotetext{
168 Ibid 89.

169 Freckelton et al (n 131) 11.

170 See, e.g., Brandon L Garrett et al, 'Forensic Science in Legal Education' (forthcoming) Journal of Law and Education.

${ }^{171}$ Commonwealth v Serge, 586 Pa 671, 896 A 2d 2006 (2006) ('Serge'): members of the court, in obiter, stated that when the adverse party cannot afford rebuttal testimony, the rule that balances probative value against unfair prejudice would be enlivened.
} 
robust adversarial testing. ${ }^{172}$ In other words, courts will excuse some lack of testing in the instant case under the theory that if a type of expert evidence has been admitted before, it must have been tested then. This reasoning is fatally flawed and can lead to ironic and dangerous results. For instance, in Forbes $v$ The Queen, the court referred to the longstanding acceptance of fingerprint evidence as a reason that it was safe to base a decision almost solely on DNA evidence: '...fingerprint evidence, which in some respects is analogous to DNA evidence, is routinely admitted and may be decisive.' ${ }^{173}$ This decision is flawed in two respects. First, fingerprint evidence has been widely admitted in Australia, but its reliability has almost never been challenged. ${ }^{174}$ Second, it is more error prone than DNA analysis and so its historic acceptance is not a good reason to admit DNA evidence without scrutiny. ${ }^{175}$

Similar to Forbes, in Canada, one court held that bitemark analysis (i.e., comparing a found bitemark to a suspect's dental impression), a practice that was never formally tested and is now known to have contributed to many wrongful convictions, was reliable. ${ }^{176}$ It did this by referring to the acceptance of bitemark analysis in US courts. 'The use of dental impressions to match bite marks is accepted in numerous American jurisdictions.' ${ }^{177}$ However, one of the decisions the court cited was a conviction of an individual who was later exonerated based on DNA evidence. Without something more, adversarial testing should not be confused with severe testing.

\footnotetext{
${ }^{172}$ Forbes $v$ The Queen [2009] ACTCA 10 [39] ('Forbes'); $R v$ Xie (No 4) [2014] NSWSC 500 [331]; Transcript of Voir Dire Proceedings, $R v$ Nguyen (Queensland District Court, Rafter DCJ, 2018) <https://osf.io/kvz4m/>.

${ }^{173}$ Forbes (n 172) [39].

${ }^{174}$ For a thorough review of the challenges to fingerprint evidence in Australia, see: Gary Edmond, 'Latent Science: A History of Challenges to Fingerprint Evidence in Australia' (2019) 42(3) University of Queensland Law Journal 301.

175 PCAST Report (n 152) 69-75, 87-103.

${ }^{176}$ See Chin and White (n 16) 96-8.

177 Ibid 97.
} 
A final reason that reliance on previous adversarial testing is so dangerous can be found in a further analogy to science. Failed adversarialism in science can occur when peer reviewers and a critical community of researchers do not have access to the underlying data and trials that were conducted but not reported. Therefore, they do not have the ammunition to critically appraise research, which allows it to be published, form part of the scientific record, and be relied upon by others. Similarly, failed adversarialism occurs in courts when parties, often the criminally accused, do not have access to all the testing underlying a practice and experiments conducted as part of litigation. ${ }^{178}$ The evidence is accepted anyway and, as we saw above, goes on to perpetuate itself in future cases.

\section{What should courts do about the prejudices of expert evidence?}

While we recognise that balancing probative value with unfair prejudice is fact-specific and contextual, the analysis above suggests considerable room for improvement in how courts assess putatively prejudicial expert evidence. Specifically, the research we reviewed indicates that courts do not fully appreciate the degree to which laypeople may overestimate the reliability of scientific claims. But, more than that, the judicial approach has been myopically focused on the CSI Effect (and in at least one case, significantly misconstrued it), rather than other wellresearched expert evidence stereotypes and misconceptions. Accordingly, we recommend that judges apply the discretions to exclude evidence in sections 135 and 137 of the UEL in a way that is more sensitive to empirical research. For example, courts should recognise that experts, or counsel that emphasise the expert's status and years of experience, also feed into that evidence's prejudicial potential. Moreover, technical jargon and the general complexity of the evidence can

\footnotetext{
${ }^{178}$ Chin, Mellor, and Growns (n 129); Edith Beerdsen, 'Litigation Science after the Knowledge Crisis.' (2021)
} 106(2) Cornell Law Review 521. 
serve to heighten that prejudice, such that these features of expert evidence may build upon each other in a way that is more than additive.

The expert evidence jurisprudence is even more insensitive to research on the factors that make evidence difficult or impossible to test. For example, we struggled (as others have) ${ }^{179}$ to find decisions acknowledging that unconscious cognitive processes and associated biases invite prejudice because the unconscious is difficult to cross-examine. ${ }^{180}$ Moreover, the closest decision we could find acknowledging adversarial imbalance as a limit on adversarial testing was a US decision in obiter. ${ }^{181}$ And troublingly, courts sometimes simply mistake previously admitted evidence with evidence that has been adversarially tested. With evidence that defies testing, the first step for courts is to acknowledge this research on prejudice and incorporate it into the exclusionary calculus in sections 135 and 137 . The next step, as we will see in the following part, is to use this knowledge to better understand the limitations of judicial directions aimed at mitigating prejudice - and perhaps craft better directions in the future.

\section{PART IV. DO JUDICIAL DIRECTIONS MITIGATE PREJUDICE?}

While some of the forms of prejudice we discussed have been acknowledged by courts, in those cases the associated evidence is still often admitted. In these circumstances, courts reference trial and adversarial safeguards, suggesting they mitigate prejudice. ${ }^{182}$ We have already pushed back on this theory, suggesting that, in criminal cases, robust testing of expert evidence through cross-examination and the testimony of a counter-expert is rare. However, a lower cost

\footnotetext{
179 Gary Edmond et al, Contextual Bias (n 157) footnote 2: 'We identified no sustained discussion or responses to "contextual bias" or "cognitive bias" in reported appellate judgments in England, Australia and Canada, though there are several passing references...'; Chin, Lutsky, and Dror (n 156).

180 Rich (n 165).

181 Serge (n 171).

${ }^{182} R$ v Shamouil (2006) 66 NSWLR 228, 239 [77]; Collins Thomson Pty Ltd (in liq) v Clayton [2002] NSWSC 366, [24]-[26]; Fagenblat v Feingold Partners Pty Ltd [2001] VSC 454, [8]; Chen (n 41) 928 [75]; Rv Cook [2004] NSWCCA 52, [37]-[52].
} 
option, and one that courts seem particularly optimistic about, ${ }^{183}$ is a judicial direction that would instruct the jury to be cautious about the expert evidence they have heard. After discussing the content of judicial directions, we will evaluate the basis for the claim that they decrease prejudice. As we will see, much of the research and law reform in this area has been focused on simplifying directions, with relatively little attention paid to expert evidence directions specifically. ${ }^{184}$

We can get a general sense of judicial directions from excerpts in appeals and from the judicial benchbooks that guide judges in crafting their directions. ${ }^{185}$ From these sources, we see that directions mainly contain general precautionary statements. For instance, they say: the jury need not accept the expert's evidence; the expert opinion depends on the reliability of the facts provided to the expert; and experts may vary in skill, knowledge, and training. We noticed one troubling direction in the NSW benchbook: 'The expert evidence has not been challenged.

${ }^{183}$ For judicial reliance on directions about expert witnesses, see: Ramaros (n 60) [37], [46]; $R v$ Martin (No 5) [2017] NSWSC 1297 [12]-[13]; Tuite (n 27) [125]-[26]; Davey v Tasmania [2020] TASCCA 12 [58] (the warning in Davey pertained to the evidence being both expert opinion evidence and voice identification evidence) ('Davey'); $R$ $v$ Ali [2015] NSWCCA 72 [52]; outside the expert context, see: DPP v Lyons and Lyons (Ruling No 3) [2018] VSC 224 [58] ('Lyons'); Farhat (n 4) [44]; $R$ v Dickman [2017] HCA 24 [30].

${ }^{184}$ For empirical research on comprehension and simplification, see See Neil Brewer, Sophie Harvey, and Carolyn Semmler, 'Improving comprehension of jury instructions with audio-visual presentation' (2004) 18(6) Applied Cognitive Psychology 765; Chantelle M Baguley, Blake M McKimmie, and Barbara M Masser, 'Re-evaluating how to measure jurors' comprehension and application of jury instructions' (2020) 26(1) Psychology, Crime \& Law 53; The New South Wales Law Reform Commission project was animated by concerns about the comprehensibility and complexity of instructions, but did include a chapter about expert evidence, which was largely focused on DNA evidence (reflecting our general concern that any guidance for drafting expert evidence directions must be quite field of expertise specific): NSWLRC 136 (n 104) 1,2, 23-6, 75-111. The Victorian Law Reform Commission was also especially concerned about complexity, but was largely silent on directions in expert cases: Victorian Law Reform Commission, Jury Directions: Final Report (2009) 8. More generally, changing another's mind after they have been misinformed is challenging: Stephan Lewandowsky et al, 'Misinformation and Its Correction: Continued Influence and Successful Debiasing' (2012) 13(3) Psychological Science in the Public Interest 106.

185 Judicial College of Victoria, 'Victorian Criminal Charge Book'

〈https://www.judicialcollege.vic.edu.au/eManuals/CCB/index.htm>; Judicial Commission of New South Wales, 'Criminal Trial Courts Bench Book — Trial Instructions A-G' <https://www.judcom.nsw.gov.au/publications/benchbks/criminal/expert evidence.html >, Expert evidence ('NSW Benchbook'); for relatively lengthy excerpts in appeals, see Davey (n 183) [57]; Kheir v The Queen [2014] VSCA 200 [45]. A systematic review of full directions is a worthwhile project, that is somewhat impractical because of the cost of obtaining trial transcripts in Australia: New South Wales Law Reform Commission, 'Open justice review' 〈https://www.lawreform.justice.nsw.gov.au/Pages/lrc/lrc current_projects/Courtinformation/Project_update.aspx> 
Accordingly, if it is not inherently unbelievable, you would need to have a good reason to reject it... ${ }^{186}$ As we discussed, there are many systemic reasons an expert might not be challenged, yet still provide unreliable evidence. Finally, as we will return to below, these directions do not contain any specialised knowledge. In other words, if an expert has overstated the reliability of their opinion, it would be neither legal nor practical for a judge to research that issue and provide, for instance, evidence that the practice being relied upon has a high error rate. ${ }^{187}$ In addition to examining the content of directions, it may also be useful to discuss the reasons judges give for trusting that they will reduce prejudice. In reviewing some of these cases, we found judges do not often provide much justification. Some reliance appears to be based on little more than faith in the direction itself ('Once the required warnings are given, no question of unfair prejudice within the meaning of s 137 of the Evidence Act is likely to be discernible') ${ }^{188}$ and in the jury ('Jurors are not stupid. The law should not treat them as though they were.'). ${ }^{189}$ We also found one case in which a court said that prior judicial experiences supported the utility of directions: 'It is the long experience of the law that juries are consistently conscientious in adhering to such directions.' ${ }^{190}$ But what feedback loop could the court be referring to here? Judges do not survey jurors about their comprehension and application of directions. And, even if that were possible, there is no ground truth in most cases to know whether jurors weighted the expert evidence appropriately.

\footnotetext{
${ }^{186}$ NSW Benchbook (n 182).

187 Although it appears rare in practice, a judge might still invite parties to make submissions on a topic such as the error rate of a forensic technique, thus bringing it into evidence via traditional adversarial means.

188 Davey (n 185) [58].

${ }^{189}$ Ramaros (n 60) [37]; see also 'any perceived prejudice that might arise from the complexity of the evidence [...] could be addressed by a strong direction that the jury must not act on the [DNA analysis software] conclusions unless they are wholly satisfied that they are soundly based in the evidence that they have heard and underst ood.': Tuite (n 27) [125].

${ }^{190}$ Lyons (n 183) [58], although note this was not in reference to an expert witness direction.
} 
Even when courts find that directions would be insufficient in lessening unfair prejudice, the reasons offered for that decision can be quite bare. Consider DPP v Paulino, a case in which the prejudice was the CSI effect (defendant's effect). ${ }^{191}$ The court simply stated: 'In my view, in the circumstances of this case, the risk of unfair prejudice flowing from the introduction of the disputed DNA evidence could not adequately be mitigated by directions.' 192 The same was the case in DPP $v$ Wise. ${ }^{193}$ These decisions run contrary to the decision in Ramaros, considering the very same unfair prejudice: 'Whilst recognising the danger of the 'CSI effect', which was discussed in Wise and Paulino, I am of the view that directions can substantially ameliorate, if not eliminate, that danger.' ${ }^{194}$ Here, we acknowledge that balancing probative value and unfair prejudice is highly fact-specific. Still, it would be useful for judgments like these to explain what it is about these cases that distinguish them such that directions would be more effective in these cases than in others. Is it the complexity of the technical issues? Or, the influence of a particularly persuasive expert? And, for our purposes, better articulating the sources of what appears to be judicial folklore would help us evaluate whether there is any truth to them. In any event, we will now turn to the available research on judicial directions.

We begin by noting that while there is research on the comprehensibility and clarity of judicial directions generally, ${ }^{195}$ there is very little on the specific question of whether they can improve the way in which lay people evaluate expert evidence. ${ }^{196}$ This lack of empirical testing

\footnotetext{
191 Paulino (n 60).

192 Ibid [104].

193 Wise (n 58) [70]: 'By virtue of its scientific pedigree, however, a jury will likely regard it as being cloaked in an unwarranted mantle of legitimacy — no matter the directions of a trial judge — and give it weight that it simply does not deserve.'.

${ }^{194}$ Ramaros (n 60) [37], [46].

195 Brewer, Harvey, and Semmler (n 184); Baguley, McKimmie, and Masser (n 184).

196 The New South Wales Law Reform Commission acknowledged this, NSWLRC 136 (n 104) 102: 'There is limited evidence about whether expert evidence or judicial directions can improve jurors' knowledge, and even more limited evidence about which is more effective.'.
} 
should raise serious red flags with respect to the decisions that uncritically state or imply that directions are a panacea for prejudicial expert evidence. We will review some of the general research on directions but caution about extending this to the context of expert evidence. Importantly, we hope this article prompts additional legal-psychological research to fill these gaps in knowledge we identify.

First, and generally speaking, jurors struggle to comprehend judicial directions. Specifically, while they report that they find them easy to follow, ${ }^{197}$ studies measuring juror comprehension (e.g., by testing jurors on their understanding of the directions) suggest that these directions are not well understood ${ }^{198}$ and often play a small role in their decisions. ${ }^{199}$ Attempts to simplify jury directions, such as removing technical language and providing factfinders with other resources alongside the directions (e.g., decision aids, written versions of the instructions) have been met with qualified success. ${ }^{200}$ We are unaware of any such reforms to directions pertaining to experts specifically.

The use of jury directions relating to expert witness evidence assumes that jurors are able to disregard parts of the expert evidence that the juror does not find sufficiently convincing or understandable. ${ }^{201}$ In other words, if a judge tells the jury to disregard or place less weight on

\footnotetext{
${ }^{197}$ Blake M McKimmie, Emma Antrobus, and Chantelle Baguley, 'Objective and Subjective Comprehension of Jury Instructions in Criminal Trials' (2014) 17(2) New Criminal Law Review 163; Athan P Papailiou, David V Yokum, and Christopher T Robertson, 'The novel New Jersey eyewitness instruction induces scepticism but not sensitivity' (2015) 10(12) PloS ONE e0142695; Lily Trimboli, 'Juror understanding of judicial instructions in criminal trials' (2008) 119 Crime and Justice Bulletin 1.

${ }^{198}$ Brewer, Harvey, and Semmler (n 181); Kristy A Martire and Richard I Kemp, 'The impact of eyewitness expert evidence and judicial instruction on juror ability to evaluate eyewitness testimony' (2008) 33(3) Law and Human Behavior 225; Carolyn Semmler and Neil Brewer, 'Using a flow-chart to improve comprehension of jury instructions' (2002) 9(2) Psychiatry, Psychology and Law 262.

${ }^{199}$ McKimmie, Antrobus, and Baguley (n 197).

${ }^{200}$ For a review, see: Chantelle M Baguley, Blake M McKimmie, and Barbara M Masser, 'Deconstructing the simplification of jury instructions: How simplifying the features of complexity affects jurors' application of instructions' (2017) 41(3) Law and Human Behavior 284; Baguley, McKimmie, and Masser (n 184).

${ }^{201}$ Tuite (n 27) [125].
} 
any part of the expert evidence that they think is unreliable, there is an assumption that they can do this. Once again, there is no research that we are aware of that has supported this assumption. More broadly speaking though, the research on disregarding inadmissible evidence suggests that these instructions are ineffective. ${ }^{202}$ Recent research also suggests that jurors make the conscious decision to use inadmissible evidence in formulating a verdict, even when instructed not to. ${ }^{203}$ As such, it is possible that by highlighting the issues with expert witness reliability during judicial directions, the expert testimony may instead become more salient and thus be given more weight in juror decision making. Note, however, that further research is needed to test these hypotheses.

To better understand the effectiveness of judicial directions for expert evidence, we can turn to the better-studied question of how directions affect jurors' reliance on unreliable eyewitness identification evidence. The general message here is that researchers have found little support for the effectiveness of such directions. ${ }^{204}$ These include studies that have examined very comprehensive directions that go so far as to refer to research explaining why certain eyewitnessing conditions can reduce the reliability of an identification. ${ }^{205}$ They generally find that if directions do have any effect (and some studies find they do not), ${ }^{206}$ they may produce some

\footnotetext{
${ }^{202}$ Nancy Steblay et al, 'The Impact on Juror Verdicts of Judicial Instruction to Disregard Inadmissible Evidence: A Meta-Analysis' (2006) 30(4) Law and Human Behavior 469.

${ }^{203}$ Berkeley J Dietvorst and Uri Simonsohn, 'Intentionally "biased": People purposely use to-be-ignored information, but can be persuaded not to (2019) 148(7) Journal of Experimental Psychology: General 1228.

${ }^{204}$ Brian L Cutler, Hedy R Dexter, and Steven D Penrod, 'Nonadversarial Methods for Sensitizing Jurors to Eyewitness Evidence' (1990) 20(14) Journal of Applied social Psychology 1197; Angela Jones et al, 'Comparing the effectiveness of Henderson instructions and expert testimony: Which safeguard improves jurors' evaluations of eyewitness evidence?' (2017) 13(1) Journal of Experimental Criminology 29; Martire and Kemp (n 194); for a review, see Alena Skalon, Mehera San Roque, and Jennifer L Beaudry, 'An Interdisciplinary and Cross-national Analysis of Legal Safeguards for Eyewitness Evidence' in Brian H Bornstein and Monica K Miller (eds) Advances in Psychology and Law (Springer, 2020) 137.

205 Papailiou, Yokum, and Robertson (n 197); Jones et al (n 204).

${ }^{206}$ Cutler, Dexter, and Penrod (n 204); Jones et al (n 204); Martire and Kemp (n 198).
} 
scepticism in the identification, ${ }^{207}$ but do not help jurors calibrate the weight they put on them (such that they place more weight on stronger identifications and less weight on weaker ones). We expect the same limits would be present with expert evidence directions, but to an even greater extent. This is because eyewitness directions are more specific than expert witness directions. For example, benchbook directions for eyewitnesses canvass specific issues such that judges can pull out the parts that are relevant to their facts (e.g., to say that identifications tend to be less reliable when made by someone of a different racial group than the person identified). On the other hand, the benchbook directions for expert evidence are very general and do not speak to any specific threats to reliability. All that such a general direction could produce is scepticism. Moreover, there is no published empirical evidence we are aware of to suggest they do even that. The most specific guidance for trial judges comes in model directions for DNA evidence, which incidentally is one of the most reliable forensic practices and thus produces relatively less prejudice. $^{208}$

More generally, expert evidence directions seem to require more epistemic content than eyewitness directions. By this, we mean that generally warning jurors that they need not accept expert evidence and that it may not be reliable does not provide the knowledge needed to evaluate expert evidence. For instance, it does not provide the error rate associated with various forensic practices. It does not discuss unconscious biases that affect experts in all litigation contexts. It does not explain the testing that has been conducted and whether that testing was severe enough to reveal flaws in the evidence. And, if such knowledge could be incorporated into judicial directions, it would be difficult to update that knowledge as more research is

\footnotetext{
207 Papailiou, Yokum, and Robertson (n 197).

208 NSWLRC 136 (n 104) 85-8. Note, however, that DNA samples can be contaminated, such that the accused's DNA profile was present in a sample for innocent reasons, leading to misuse and prejudice.
} 
conducted. Compounding these problems, even if all of these hurdles could be met, such directions would very likely offend the rules of judicial notice (i.e., judges providing factual information on anything beyond dispute). ${ }^{209}$

Ultimately, much more legal-psychological research is needed when it comes to judicial instructions for expert evidence. From a legal perspective, and as we have noted, current directions appear insufficient to counter the unfair prejudices we canvassed in Part III. However, it is possible that judges are employing more detailed directions in practice. We are not aware of any systematic content analysis or other legal research on these directions (possibly due to the costs and difficulties associated with obtaining trial transcripts). Such work would be useful in providing examples that psychological researchers could test to see if they are effective. For instance, do instructions that are currently in use (and that have been developed by judicial commissions and endorsed by law reform bodies) help jurors take into account misconceptions about the trustworthiness of science? Do they help jurors downgrade the weight they place on evidence that has not withstood severe testing? Until such work is available, uncritical reliance on directions as a curative for prejudicial expertise is misguided.

\section{PART V. CONCLUSIONS AND FUTURE DIRECTIONS}

In this article, we have sought to draw together research findings from multiple fields and explain how they relate to the $U E L$ 's unfair prejudice doctrine. This analysis also largely applies to states that retain the common law of evidence, where the concept of unfair prejudice works similarly. ${ }^{210}$ By connecting this research to specific aspects of unfair prejudice law and

\footnotetext{
${ }^{209}$ See, e.g., UEL (n 1) s 144.

210 See Festa v The Queen [2001] HCA 72 discussing unfair prejudice as misuse of evidence. Although note that the need for an empirically-sound application of unfair prejudice is perhaps less urgent in common law states, where opinion evidence can still lack probative value because it is not demonstrably reliable: Pentland (n 9). Recall also that the US, UK, and Canada have rules that balance probative value against unfair prejudice: FRE (n 9) at r 403; PACE (n 9) at s 78; Morris (n 9). One curiosity within the UEL jurisprudence, worth tracking, is the suggestion that
} 
highlighting where the research is both applicable and lacking, we hope to encourage further development of both the law and the empirical research. ${ }^{211}$ That said, a better understanding of unfair prejudice offers just one step towards a more empirically sophisticated balancing of probative value and unfair prejudice. For instance, probative value and prejudice are in some ways incommensurables, making it difficult to balance them precisely. Moreover, the rule in $I M M$ to take the reliability of evidence at its highest makes it challenging for any amount of unfair prejudice to exceed probativeness. ${ }^{212}$ With those challenges in mind - and with an eye towards the future - we will conclude by emphasising a few key strengths and limits of what we currently know about the unfair prejudice of experts.

First, there is longstanding evidence that some aspects of the scientific process are not clear to lay people. Consequently, this can lead them to overestimate the reliability of scientific findings and methods. For instance, many people seem to believe that fuller reporting of the strengths and weaknesses of research is more common than it is. ${ }^{213}$ Moreover, even scientists themselves can be fooled into giving more weight to scientific research when they think it was conducted by a prestigious colleague. ${ }^{214}$ Turning to forensic science, a regular player in criminal matters, we saw that, despite the assessment of at least one Australian court, there is little reason to think that popular depictions of crime labs on television screens raise expectations of how

that unfair prejudice may be affected by evidence's lack of reliability: Xie (n 93) [301]. However, we are not aware of any sustained analysis of this point.

${ }^{211}$ While we have confined our analysis to the rules as currently written, another approach, preferable in its simplicity, would be to amend the UEL. Indeed, the last systematic look at the UEL as a whole - in which the opinion rules were left largely untouched - was over 15 years ago: ALRC 102 (n 52). Indeed, Maxwell (n 2) recently suggested amending the UEL's expert evidence rules.

${ }^{212}$ Farhat (n 4) [37]-[38]: 'the possible use to which the evidence might be put must be taken at its highest [...]

Thus, the probative value of Sgt of Bishop's evidence is to be assessed on the basis that its credibility and reliability is accepted by a jury.'

${ }^{213}$ Pickett and Roche (n 87).

${ }^{214}$ Kanu Okike (n 119); Tomkins, Zhang, and Heavlin (n 119). 
things work in reality, and thus disadvantage the prosecution (i.e., the prosecutor's effect). ${ }^{215}$ Rather, forensic sciences' (sometimes unearned) scientific patina likely misleads many factfinders into giving it too much weight.

Thanks to the work of scientific oversight bodies and other researchers, we also know quite a bit about what requires more testing and why that testing is important. Notably, research into forensic science is uncovering considerable gaps in knowledge: several fields have never been tested (let alone severely tested) such that we can be confident that they work under realistic conditions. Psychological research on unconscious processes and biased cognition provides robust demonstrations for why severe testing is important. A host of psychological biases affect experts in ways they are often unaware of and may discount. ${ }^{216}$ Put simply, we are learning a great deal more about the limits of our knowledge and why those limits exist.

These insights about what people do and do not understand about expert evidence should prompt work into how to convey such knowledge to factfinders. Some such work is already underway. For instance, Martire and colleagues recently developed eight 'broad attributes that are logically relevant to the merit-based assessment of an expert opinion', such as whether the underlying practice or theory has been tested and if the expert witness is demonstrably proficient in the method. ${ }^{217}$ They have found that mock jurors will use some types of evidence from this framework when provided with it. This suggests jurors can be trusted, to an extent, to use the information scientists think are valuable. Moreover, ongoing research finds that evidence from the framework may even decrease reliance on peripheral information (e.g., the expert's gender). That is, when given useful information to judge the reliability of expert evidence, factfinders

\footnotetext{
215 Podlas (n 57).

216 Chin, Lutsky, and Dror (n 156) 24-30.

${ }^{217}$ Kristy A Martire, Gary Edmond, and Danielle Navarro, 'Exploring juror evaluations of expert opinions using the Expert Persuasion Expectancy framework’ (2020) 25(2) Legal and Criminological Psychology 90.
} 
may prefer that over prejudicial stereotypes. ${ }^{218}$ This promising work should be replicated and systematically expanded. For instance, researchers should test whether people will readily and appropriately discount the evidence of high-status experts or those with a great deal of experience when given information to suggest that their method is poorly tested or that their own ability has not been well-tested.

Finally, this work on how to encourage factfinders to scrutinise the merits of expert evidence should feed into further legal and psychological research into improving judicial directions about expert evidence. This is a safeguard that judges seem particularly enthusiastic about, but one that has received considerably little research. By way of analogy to other types of directions, we suggested that directions are likely not nearly as effective as judges expect. However, more direct research is needed to support this conclusion. Looking towards the future, legal-psychological collaborations should test both the effectiveness of expert evidence directions and explore ways to improve them. For instance, current judicial notice rules forbid judges from providing knowledge about evidence's reliability. However, would instructions about what jurors were not presented with be allowable under the $U E L$ and would they be effective? For example, judicial directions about eyewitness memory already toe the line with respect to judicial notice by providing knowledge about how human memory works. Could similar directions be crafted for expert evidence, explaining that many fields have not been validated and that jurors should consider the presence and absence of severe testing? And, would jurors use this knowledge appropriately? Until such evidence-based directions are developed, courts should not be so willing to simply assume that current directions can mitigate the prejudices of expert evidence.

218 Younan and Martire (135). 


\section{Table 1. Eight prejudices of expert evidence}

Table 1 lays out each of the prejudices in Part III, a key research article describing the prejudice, and a decision in which a court recognised this prejudice (when available).

\begin{tabular}{|c|c|c|c|}
\hline Prejudice & Description & $\begin{array}{l}\text { Academic / } \\
\text { research } \\
\text { source }\end{array}$ & $\begin{array}{l}\text { Related legal } \\
\text { authority (if } \\
\text { available) }\end{array}$ \\
\hline $\begin{array}{l}\text { Overconfidence in } \\
\text { scientific claims and } \\
\text { safeguards }\end{array}$ & $\begin{array}{l}\text { Overweight scientific evidence; } \\
\text { assume transparency and robustness }\end{array}$ & $\begin{array}{l}\text { Pickett \& Roche } \\
\text { (2017) }\end{array}$ & $\begin{array}{l}R v \text { Dirani }[2018] \\
\text { NSWSC } 891[112]\end{array}$ \\
\hline $\begin{array}{l}\text { CSI Effect (defence } \\
\text { attorney's effect) }\end{array}$ & $\begin{array}{l}\text { Overweight forensic science } \\
\text { evidence }\end{array}$ & Podlas (2017) & $\begin{array}{l}\text { DPP } v \text { Wise }[2016] \\
\text { VSCA } 173[70]\end{array}$ \\
\hline $\begin{array}{l}\text { Expert evidence } \\
\text { stereotypes }\end{array}$ & $\begin{array}{l}\text { Overweight stereotypical expertise } \\
\text { (e.g., gender-congruent, high-status, } \\
\text { highly experienced) }\end{array}$ & Okike (2016) & $\begin{array}{l}\text { Rees v Lumen Christi } \\
\text { Primary School [2010] } \\
\text { VSC 514 [50]- status } \\
\text { bias }\end{array}$ \\
\hline $\begin{array}{l}\text { Peripheral route } \\
\text { processing }\end{array}$ & $\begin{array}{l}\text { Enhances reliance on stereotypes, } \\
\text { presumptions about the field (e.g., } \\
\text { CSI effect) }\end{array}$ & $\begin{array}{l}\text { Petty \& } \\
\text { Cacioppo } \\
(1984)\end{array}$ & $\begin{array}{l}\text { Aytugrul v The Queen } \\
\text { [2012] HCA } 15\end{array}$ \\
\hline $\begin{array}{l}\text { Absence of severe } \\
\text { tests }\end{array}$ & $\begin{array}{l}\text { Information not available to } \\
\text { critically appraise expert's claims; } \\
\text { assume evidence has been severely } \\
\text { tested when it has not been }\end{array}$ & $\begin{array}{l}\text { President's } \\
\text { Council of } \\
\text { Advisors on } \\
\text { Science and } \\
\text { Technology } \\
\text { Report (2016) }\end{array}$ & $\begin{array}{l}\text { Kyluk } v \text { Chief } \\
\text { Executive, Office of } \\
\text { Environment and } \\
\text { Heritage [2013] } \\
\text { NSWCCA } 114 \text { [65] }\end{array}$ \\
\hline Black box experts & $\begin{array}{l}\text { Witness cannot report on } \\
\text { unconscious thoughts; impervious to } \\
\text { cross-examination; cognitive bias }\end{array}$ & $\begin{array}{l}\text { Searston \& } \\
\text { Chin (2019) }\end{array}$ & $\begin{array}{l}(A S I C) \text { v Rich [2005] } \\
\text { NSWSC } 149 \text { [377] }\end{array}$ \\
\hline $\begin{array}{l}\text { Adversarial } \\
\text { imbalance }\end{array}$ & $\begin{array}{l}\text { Evidence is practically untestable } \\
\text { because defence is underfunded to } \\
\text { research area of expertise and } \\
\text { appoint own expert }\end{array}$ & $\begin{array}{l}\text { Freckelton et al } \\
\text { (2016) } 11\end{array}$ & $\begin{array}{l}\text { Commonwealth } v \\
\text { Serge, } 586 \text { Pa 671, } \\
896 \text { A 2d } 2006\end{array}$ \\
\hline $\begin{array}{l}\text { Adversarially } \\
\text { untested }\end{array}$ & $\begin{array}{l}\text { Previous proceedings in which } \\
\text { evidence was admitted are not } \\
\text { themselves testable; overweight } \\
\text { evidence accepted in prior } \\
\text { proceedings }\end{array}$ & Edmond (2019) & - \\
\hline
\end{tabular}


Table 2. Disambiguating the CSI Effects

The term 'CSI Effect' encompasses a multitude of definitions. Table 2 summarises the key differences between the two main CSI Effects.

\begin{tabular}{|l|l|l|l|}
\hline CSI Effect & Description & Robust empirical support? & $\begin{array}{l}\text { Recognition in an } \\
\text { Australian case }\end{array}$ \\
\hline $\begin{array}{l}\text { Defendant's } \\
\text { effect }\end{array}$ & $\begin{array}{l}\text { Factfinders place too much weight } \\
\text { on forensic scientific evidence }\end{array}$ & Yes & $\begin{array}{l}\text { DPP v Wise [2016] VSCA } \\
173\end{array}$ \\
\hline $\begin{array}{l}\text { Prosecutor's } \\
\text { effect }\end{array}$ & $\begin{array}{l}\text { Factfinders evaluate prosecution's } \\
\text { case less favourably because of } \\
\text { unrealistic expectations from } \\
\text { popular culture }\end{array}$ & No & $\begin{array}{l}\text { Xie v The Queen [2021] } \\
\text { NSWCCA 1 }\end{array}$ \\
\hline
\end{tabular}




\section{Author Contributions ${ }^{219}$}

Conceptualization: Jason M. Chin.

Investigation: Jason M. Chin, Hayley J. Cullen, and Beth Clarke.

Project administration: Jason M. Chin.

Writing - original draft: Jason M. Chin, Hayley J. Cullen, and Beth Clarke.

Writing - review \& editing: Jason M. Chin, Hayley J. Cullen, and Beth Clarke.

219 Alex O Holcombe et al, 'Documenting contributions to scholarly articles using CRediT and tenzing' (2020) 15(12) PLoS ONE e0244611. 